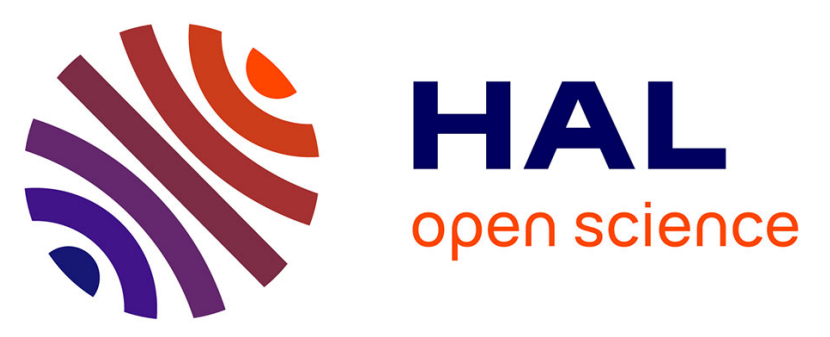

\title{
Effect of postsynthesis preparation procedure on the state of copper in CuBEA zeolites and its catalytic properties in SCR of NO with NH3
}

Rafal Baran, Frederic Averseng, Dominik Wierzbicki, Karolina Chalupka, Jean-Marc Krafft, Teresa Grzybek, Stanislaw Dzwigaj

\section{To cite this version:}

Rafal Baran, Frederic Averseng, Dominik Wierzbicki, Karolina Chalupka, Jean-Marc Krafft, et al.. Effect of postsynthesis preparation procedure on the state of copper in CuBEA zeolites and its catalytic properties in SCR of NO with NH3. Applied Catalysis A: General, 2016, 523 pp.332-342. 10.1016/j.apcata.2016.06.008 . hal-01329581

\section{HAL Id: hal-01329581 \\ https: / hal.sorbonne-universite.fr/hal-01329581}

Submitted on 9 Jun 2016

HAL is a multi-disciplinary open access archive for the deposit and dissemination of scientific research documents, whether they are published or not. The documents may come from teaching and research institutions in France or abroad, or from public or private research centers.
L'archive ouverte pluridisciplinaire HAL, est destinée au dépôt et à la diffusion de documents scientifiques de niveau recherche, publiés ou non, émanant des établissements d'enseignement et de recherche français ou étrangers, des laboratoires publics ou privés. 


\section{Effect of postsynthesis preparation procedure on the state of}

\section{copper in CuBEA zeolites and its catalytic properties in SCR of}

\section{$\mathrm{NO}$ with $\mathrm{NH}_{3}$}

Rafal Baran ${ }^{1,2,3}$, Frederic Averseng ${ }^{2,3}$, Dominik Wierzbicki ${ }^{1}$, Karolina Chalupka ${ }^{4}$, Jean-Marc $\operatorname{Krafft}^{2,3}$, Teresa Grzybek ${ }^{1}$, Stanislaw Dzwigaj ${ }^{2,3, *}$

${ }^{1}$ AGH University of Science and Technology al. A. Mickiewicza 30, 30-059 Krakow, Poland ${ }^{2}$ Sorbonne Universités, UPMC Univ Paris 06, UMR 7197, Laboratoire de Réactivité de Surface, F-75005, Paris, France

${ }^{3}$ CNRS, UMR 7197, Laboratoire de Réactivité de Surface, F-75005, Paris, France

${ }^{4}$ Lodz University of Technology, Institute of General and Ecological Chemistry, Zeromskiego 116, 90-924 Lodz, Poland

*Corresponding author:

Dzwigaj Stanislaw, E-mail : stanislaw.dzwigaj@upmc.fr, Fax : 33144272113

Figures: 10

Tables: 4 


\title{
Graphical abstract
}
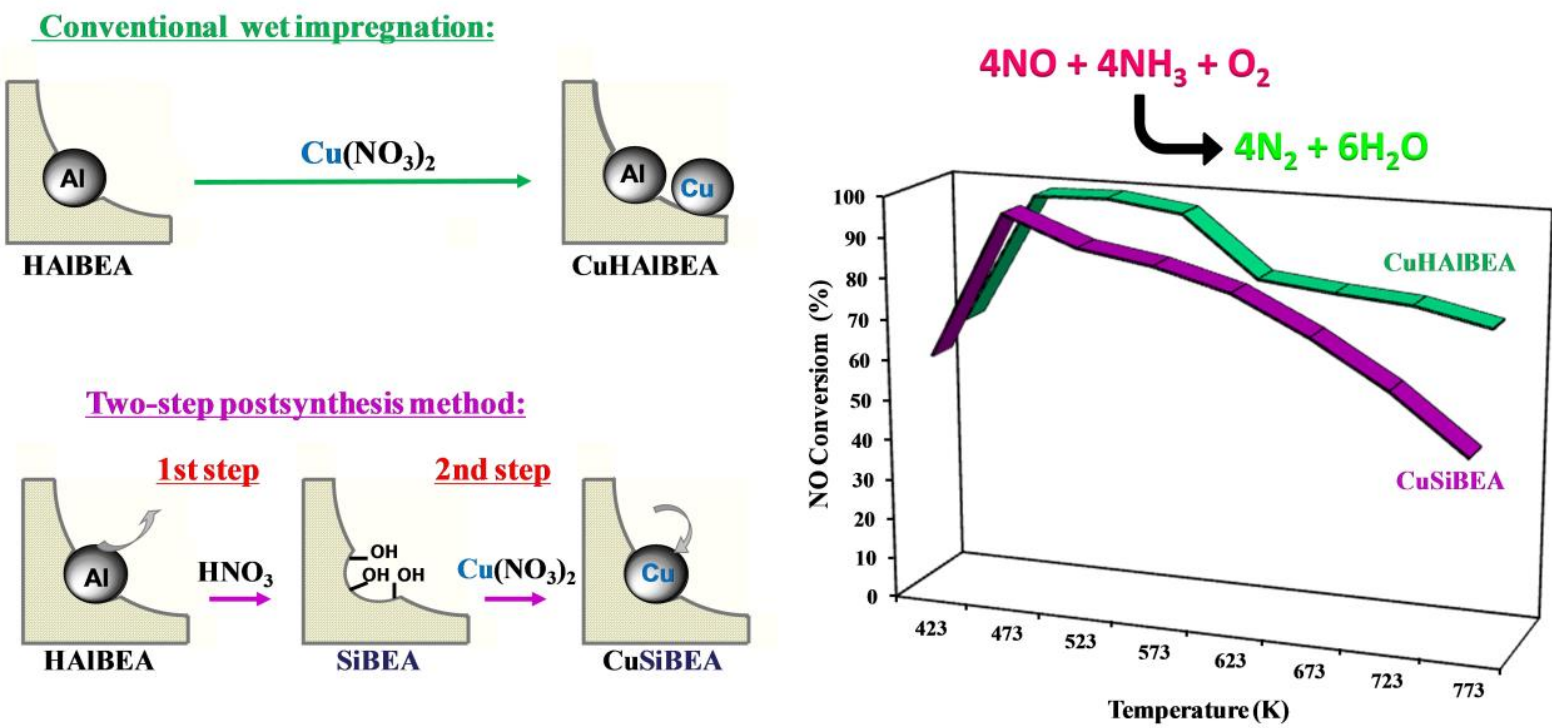

Highlights

- In Cu2.0HAIBEA mainly extra-framework octahedral $\mathrm{Cu}$ (II) was present.

- In Cu2.0SiBEA mainly framework mononuclear $\mathrm{Cu}$ (II) was occurred.

- Both Cu2.0HAIBEA and Cu2.0SiBEA catalysts showed high activity in SCR NO with $\mathrm{NH}_{3}$.

- The state of copper as well as the acidity plays an important role in SCR of NO.

\begin{abstract}
Copper-containing BEA zeolites, $\mathrm{Cu}_{2.0} \mathrm{SiBEA}$ and $\mathrm{Cu}_{2.0} \mathrm{HAlBEA}$, with 2 wt $\%$ of $\mathrm{Cu}$ were prepared by a two-step postsynthesis method and a conventional wet impregnation, respectively. These zeolites were characterized by XRD, DR UV-vis, EPR, FTIR and TPR physicochemical techniques. The incorporation of $\mathrm{Cu}$ into framework of SiBEA was evidenced by XRD. The state of copper in both zeolites was investigated by DR UV-vis and EPR. The acidity of $\mathrm{Cu}_{2.0} \mathrm{SiBEA}$ and $\mathrm{Cu}_{2.0} \mathrm{HAlBEA}$ was determined by FTIR of adsorbed $\mathrm{CO}$ and pyridine. The reducibility of the $\mathrm{Cu}$ species present in both zeolites was studied by TPR and their catalytic properties were investigated in selective catalytic reduction of NO with
\end{abstract}


$\mathrm{NH}_{3}$. Both $\mathrm{Cu}_{2.0} \mathrm{SiBEA}$ and $\mathrm{Cu}_{2.0}$ HAlBEA zeolite catalysts showed very high activity in this reaction with the NO conversion higher than $80 \%$ and $\mathrm{N}_{2}$ selectivity higher than $95 \%$ in the temperature range between 473 and $623 \mathrm{~K}$. The higher NO conversion and $\mathrm{N}_{2}$ selectivity in SCR of NO with ammonia at the high temperature range for the $\mathrm{Cu}_{2.0} \mathrm{HAlBEA}$ than for $\mathrm{Cu}_{2.0} \mathrm{SiBEA}$ suggest that the strong Brønsted and Lewis acidic sites related to the framework and extra-framework aluminum atoms play an important role in SCR of NO process.

Keywords: Copper, Beta zeolites, $\mathrm{NH}_{3}$, SCR of $\mathrm{NO}$

\section{Introduction}

Copper containing zeolites have been extensively tested in selective catalytic reduction of NO with ammonia. Especially high activity and selectivity to $\mathrm{N}_{2}$ were reported for $\mathrm{Cu}$ ZSM-5 and Cu-BEA zeolites [1-4]. However, recently, zeolites with smaller pores size, such as SSZ-13 and SAPO-34, have been indicated as the most promising materials for application in diesel systems SCR unit due to high chemical and thermal stability [5-8]. Nevertheless, further development in catalytic $\mathrm{NO}_{\mathrm{x}}$ abatement technologies is necessary due to severe environmental regulation related to nitrogen oxides emission.

The main obstacles leading to deactivation of copper containing zeolites are hydrothermal dealumination and poisoning of active species as well as migration and sintering of copper species over SCR process. A possible solution of those issues is the improvements in catalysts preparation methods. An optimal catalyst preparation procedure should allow controlling the speciation of active sites and to obtain isolated species well fixed to support. Currently used conventional methods, such as ion-exchange and impregnation, leads to introduction of active species in various forms i.e. isolated framework species, isolated cations in exchange positions and extra-framework nanoclusters.

Some of scientists involved in $\mathrm{DeNO}_{\mathrm{x}}$ processes proposed a direct synthesis of $\mathrm{Cu}$ containing zeolites by the addition of organo-copper complexes in the synthesis gel as an alternative method to conventional ion exchange and impregnation [9]. However, this kind of method resulted in undesired mixture of copper in framework and extra-framework positions.

On the other hand, Dzwigaj et al. [10-12] have proposed a new method for postsynthesis modification of beta zeolite which consists of two steps. In the first step, vacant T-atom sites are created by treatment of parent zeolite with nitric acid solution. In the second 
step, the metal ions react with silanol groups of vacant T-atom sites forming framework metal species with well-defined environment.

In this work it was studied the influence of two different catalyst preparation procedures, conventional wet impregnation and two-step postsynthesis method, on the nature and environmental of copper introduced in $\mathrm{Cu}_{2.0} \mathrm{HAlBEA}$ and $\mathrm{Cu}_{2.0}$ SiBEA, respectively. Moreover, both copper containing catalysts were applied for selective catalytic reduction of NO with ammonia and their performances were compared.

\section{Experimental Section}

\subsection{Materials}

Copper-containing BEA zeolites (with $2 \mathrm{Cu}$ wt \%) were prepared from parent TEABEA zeolite by a two-step postsynthesis method $\left(\mathrm{Cu}_{2.0} \mathrm{SiBEA}\right)$ and a conventional wet impregnation $\left(\mathrm{Cu}_{2.0} \mathrm{HAlBEA}\right)$ using $\mathrm{SiBEA}$ and HAlBEA as the supports whose preparation was described in our earlier work [13].

$\mathrm{Cu}_{2.0} \mathrm{SiBEA}$ and $\mathrm{Cu}_{2.0} \mathrm{HAlBEA}$ were prepared by impregnation of $2 \mathrm{~g}$ of SiBEA and HAlBEA, respectively, with $\mathrm{Cu}\left(\mathrm{NO}_{3}\right)_{2} \cdot 6 \mathrm{H}_{2} \mathrm{O}$ solutions with appropriate concentration of copper. Firstly, the suspensions were stirred for $24 \mathrm{~h}$ at $298 \mathrm{~K}$ in excess solvent using $200 \mathrm{~mL}$ of the precursor solutions. Then, the suspensions were stirred in evaporator under vacuum of a water pump in air at $353 \mathrm{~K}$ for $2 \mathrm{~h}$ until water was evaporated. $\mathrm{Cu}_{2.0} \mathrm{SiBEA}$ and $\mathrm{Cu}_{2.0} \mathrm{HAlBEA}$ were calcined in air $\left(100 \mathrm{~K} \mathrm{~h}^{-1}\right)$ at $773 \mathrm{~K}$ for $3 \mathrm{~h}$ under static condition and labeled as C$\mathrm{Cu}_{2.0} \mathrm{SiBEA}$ and $\mathrm{C}-\mathrm{Cu}_{2.0} \mathrm{HAlBEA}$, respectively, where C- stands for calcined.

\subsection{Techniques}

X-ray Fluorescence chemical analysis was performed at room temperature on SPECTRO X-LabPro apparatus.

Copper-containing beta zeolites were investigated by chemical analysis, powder X-ray diffraction (XRD), diffuse reflectance UV-vis (DR UV-vis), electron paramagnetic resonance (EPR), Fourier transform infrared spectroscopy combined with CO sorption (CO-FTIR) and temperature programmed reduction (TPR).

XRD experiments were carried out on a PANalitical Empyrean diffractometer using the $\mathrm{CuK}_{\alpha}$ radiation $(\lambda=154.05 \mathrm{pm})$. All experiments were performed at room temperature.

DR UV-vis spectra were recorded at ambient atmosphere on a Cary 5000 Varian spectrometer equipped with a double integrator with polytetrafluoroethylene as reference. 
EPR spectra were recorded on a JEOL FA-300 series EPR spectrometer at about 9.3 $\mathrm{GHz}$ (X band) using a 100-kHz field modulation and a 5-10 G standard modulation width. The spectra were recorded at 298 and 77 K. Simulations were performed using the EPRSim32 software developed by Spalek et al [14].

Analysis of the acidic properties of samples by adsorption of pyridine (Py) followed by infrared spectroscopy was performed in the same way as is described in [15].

Infrared spectroscopy of $\mathrm{CO}$ adsorption/desorption experiments was performed on a Bruker Vertex 70 spectrometer. Before analysis, self-supported samples were pressed at ca. 1 ton $\mathrm{cm}^{-2}$ into thin wafers of ca. $10 \mathrm{mg} \mathrm{cm}^{-2}$ and set inside the glass cell where they were pretreated at $723 \mathrm{~K}$ for $2 \mathrm{~h}$ in flowing $2.5 \% \mathrm{O}_{2} / \mathrm{Ar}$ and then degassed at $573 \mathrm{~K}\left(10^{-3} \mathrm{~Pa}\right)$ for $1 \mathrm{~h}$.

Finally, IR cell was cooled down to $100 \mathrm{~K}$ with liquid nitrogen, and $\mathrm{CO}$ was added in small portions up to an equilibrium pressure of $133 \mathrm{~Pa}$. Then, the sample was evacuated up to $10^{-3} \mathrm{~Pa}$ at room temperature. The spectra were obtained after subtraction of the spectrum recorded before $\mathrm{CO}$ adsorption.

The $\mathrm{H}_{2}$-TPR measurements were carried out on an AutoChem 2910 apparatus (Micromeretics) equipped with a thermal conductivity detector (TCD) in the temperature range of $298-900 \mathrm{~K}$ with a linear heating rate of $7 \mathrm{~K} \mathrm{~min}^{-1}$, hydrogen stream $\left(5 \% \mathrm{H}_{2} / \mathrm{Ar}\right)$ flow of $40 \mathrm{~cm}^{3} \mathrm{~min}^{-1}$ and samples weight of $0.1 \mathrm{~g}$. The copper reduction degree in $\mathrm{C}$ $\mathrm{Cu}_{2.0} \mathrm{SiBEA}$ and $\mathrm{C}-\mathrm{Cu}_{2.0} \mathrm{HAlBEA}$ were calculated in following way. From sample mass and $\mathrm{Cu}$ content were calculated the number of $\mathrm{Cu}$ mole and theoretical number of $\mathrm{H}_{2}$ moles which are needed to reduce $\mathrm{Cu}$ :

$n_{C u}=n_{H_{2}(t)}=\left(\frac{C_{C u} \times m_{s}}{100 \%}\right) /_{M_{C u}}$

where $\mathrm{n}_{\mathrm{Cu}}$ is number of $\mathrm{Cu}$ mole in the sample, $\mathrm{n}_{\mathrm{H} 2(\mathrm{t})}$ is number of $\mathrm{H}_{2}$ moles need to completely reduce $\mathrm{Cu}$ in sample, $\mathrm{m}_{\mathrm{s}}$ is sample mass and $\mathrm{M}_{\mathrm{Cu}}$ is molar mass of $\mathrm{Cu}$. From total area under the reduction peaks of standard $\mathrm{CuO}$ and the samples were calculated the number of $\mathrm{H}_{2}$ moles consumed to reduce $\mathrm{Cu}$ :

$n_{H_{2}(r)}=S_{s} \times n_{H_{2}(\mathrm{CuO})} / S_{\mathrm{CuO}}$

where: $\mathrm{n}_{\mathrm{H} 2(\mathrm{r})}$ and $\mathrm{S}_{\mathrm{s}}$ are the number of $\mathrm{H}_{2}$ mole consumed for $\mathrm{Cu}$ reduction and total area under reduction peaks for the zeolite samples, respectively, $\mathrm{n}_{\mathrm{H} 2(\mathrm{CuO})}$ is the number of $\mathrm{H}_{2}$ mole used for reduction of pure $\mathrm{CuO}$ and $\mathrm{S}_{\mathrm{CuO}}$ is the total area of reduction peak, calculated for pure $\mathrm{CuO}$ (standard). Reduction degree of $\mathrm{Cu}$ in samples was calculated form equation: 
$R_{C u}=n_{H_{2}(r)} / n_{H_{2}(t)} \times 100 \%$

where $\mathrm{R}_{\mathrm{Cu}}$ is copper reduction degree.

The activity tests of $\mathrm{Cu}_{2.0} \mathrm{SiBEA}$ and $\mathrm{Cu}_{2.0} \mathrm{HAlBEA}$ catalysts in selective catalytic reduction (SCR) of NO with ammonia were performed in a fixed bed reactor. The composition of the reaction gas was: $1000 \mathrm{ppm} \mathrm{NO}, 1000 \mathrm{ppm} \mathrm{NH}_{3}, 3.5$ vol. $\% \mathrm{O}_{2}$ and $\mathrm{He}$ as balance. The gas mixture was provided with calibrated electronic mass flow controllers (BETA-ERG). The total gas flow was $0.1 \mathrm{~L} \mathrm{~min}^{-1}$ and catalyst mass was $0.2 \mathrm{~g}$. The concentrations of $\mathrm{NO}$ and $\mathrm{N}_{2} \mathrm{O}$ after reaction were analyzed by FTIR detectors (ABB 2020 AO series). Prior to the reaction the catalyst bed was activated in $3.5 \% \mathrm{O}_{2} / \mathrm{He}$ flow $(0.1 \mathrm{~L}$ $\mathrm{min}^{-1}$ ) in the temperature range of $298-798 \mathrm{~K}$ with a linear heating rate of $2 \mathrm{~K} \mathrm{~min}^{-1}$ and then for $1 \mathrm{~h}$ at $798 \mathrm{~K}$. The standard test was carried out over $1 \mathrm{~h}$ at $573-773 \mathrm{~K}$ with increasing reaction temperature every $50 \mathrm{~K}$ interval. The NO conversion was calculated from the measured concentration of nitrogen oxide.

\section{Results and Discussion}

\subsection{Incorporation of copper into zeolite framework determined by XRD and FTIR}

\subsubsection{X-ray diffraction}

The experiments of chemical analysis of zeolite samples allowed determine the Si/Al ratio and $\mathrm{Cu}$ content and the results are showed in Table $\mathbf{1}$.

Both $\mathrm{Cu}_{2.0}$ HAlBEA and $\mathrm{Cu}_{2.0}$ SiBEA zeolites are characterized by similar XRD patterns as that of HAIBEA and SiBEA supports (Fig. 1). It indicates that introduction of copper into both type of BEA supports did not affect crystal structure of these materials. The observations of the zeolites XRD patterns before and after introduction of copper (Fig. 1) showed that for HAlBEA only negligible shift of the main diffraction peak was observed from $2 \theta=22.45^{\circ}$ to $2 \theta=22.39^{\circ}$ after introduction of copper by conventional wet impregnation. However, for the SiBEA significant shift of the main diffraction peak is observed (from $2 \theta=$ $22.72^{\circ}$ for $\mathrm{SiBEA}$ to $2 \theta=22.59^{\circ}$ for $\mathrm{Cu}_{2.0} \mathrm{SiBEA}$ ) after introduction of copper by the two-step postsynthesis method. It suggests that upon the latter preparation method copper was incorporated into framework of BEA zeolite by reaction with silanol groups of vacant T-atom sites formed in the first step of this procedure as a result of the removal of Al upon nitric acid treatment, in line with earlier investigations on CuSiBEA materials [16,17]. Moreover, for the used catalysts differences in their XRD patterns are clearly seen. For spent- $\mathrm{Cu}_{2.0} \mathrm{SiBEA}$ a large shift of the main diffraction reflection (from $22.72^{\circ}$ for SiBEA to $22.28^{\circ}$ for spent$\mathrm{Cu}_{2.0} \mathrm{SiBEA}$ ) was observed indicating that sample activation and reaction conditions led to 
strong incorporation of copper species into SiBEA zeolite framework. In contrast, for spent$\mathrm{Cu}_{2.0} \mathrm{HAlBEA}$ the position of the main diffraction peak is almost the same as for HAlBEA support, it suggest that in the case of latter support the copper was not incorporated in the zeolite framework and was predominantly present in extra-framework position.

\subsubsection{FTIR}

The FTIR spectra of HAlBEA $\mathrm{Cu}_{2.0} \mathrm{HAlBEA}$, SiBEA and $\mathrm{Cu}_{2.0} \mathrm{SiBEA}$ are shown in the Figure 2. The spectra for HAlBEA and SiBEA supports were thoroughly described in our earlier works on BEA zeolites [13,18]. The introduction of $2 \%$ of $\mathrm{Cu}$ into HAlBEA led to disappearance of broad band at $3550 \mathrm{~cm}^{-1}$, narrow band at $3781 \mathrm{~cm}^{-1}$ and decrease in the intensity of the band at $3608 \mathrm{~cm}^{-1}$ suggesting that cooper ions interacts with corresponding hydroxyl groups and some part of $\mathrm{H}^{+}$was exchanged with $\mathrm{Cu}^{2+}$ in cationic positions of HAIBEA zeolite.

The treatment of organic-free BEA zeolite with high concentrated nitric acid solution leads to removal of aluminum species and appearance in the spectrum of SiBEA the intense bands at 3735 and $3520 \mathrm{~cm}^{-1}$ of SiO-H groups (Fig. 2) due to the formation of vacant T-atom sites with hydrogen-bonded silanol groups, as reported earlier [19]. The impregnation of SiBEA with aqueous solution of cooper precursor resulted in strong decreasing of intensity of $\mathrm{OH}$ bands of hydrogen bonded silanol groups at $3520 \mathrm{~cm}^{-1}$ (Fig. 2) suggesting that $\mathrm{Cu}$ (II) reacted with these silanol groups leading to the incorporation of copper ions into framework of SiBEA.

\subsection{Nature of copper determined by DR-UV-vis and EPR}

In order to describe the chemical nature and the environment of copper in C-Cu ${ }_{2.0}$ SiBEA and C-Cu ${ }_{2.0}$ HAlBEA the DR UV-vis and EPR spectroscopies were used.

\subsubsection{DR UV-vis spectroscopy}

DR UV-vis spectra of $\mathrm{Cu}_{2.0} \mathrm{HAlBEA}$ and $\mathrm{Cu}_{2.0} \mathrm{SiBEA}$ samples contained d-d transition bands at approximately $835 \mathrm{~nm}$ and an intense charge-transfer (CT) band at $280 \mathrm{~nm}$ (Fig. 3). These bands could be assigned to the $\mathrm{d}-\mathrm{d}$ transition of $\mathrm{Cu}^{2+}\left(3 \mathrm{~d}^{9}\right)$ and $\mathrm{CT} \mathrm{O}^{2-} \rightarrow \mathrm{Cu}^{2+}$ transition of isolated mononuclear $\mathrm{Cu}(\mathrm{II})$ being in coordination with lattice oxygen, respectively [20-23]. The absence of the DR UV-vis band in the range of 300-600 nm assigned to $\mathrm{O}^{2-}$ to $\mathrm{Cu}^{2+}$ charge-transfer transition of dinuclear [20,21,24] or trinuclear [24,25] copper-oxygen complex for $\mathrm{Cu}_{2.0} \mathrm{SiBEA}$ indicates that such polynuclear complexes were not present in the latter sample. For $\mathrm{Cu}_{2.0} \mathrm{HAlBEA}$ additionally a DR UV-vis band at $400 \mathrm{~nm}$ 
occurred typical for octahedral $\mathrm{Cu}$ (II) species $[20,21,24,25]$, suggesting the presence of such species in this sample.

Calcination of both $\mathrm{Cu}_{2.0} \mathrm{HAlBEA}$ and $\mathrm{Cu}_{2.0}$ SiBEA samples at $773 \mathrm{~K}$ for $3 \mathrm{~h}$ leads to important changes in the DR UV-vis spectra. The spectra of $\mathrm{C}-\mathrm{Cu}_{2.0} \mathrm{HAlBEA}$ and C$\mathrm{Cu}_{2.0} \mathrm{SiBEA}$ are composed of a broad band at around 780-785 nm (Fig. 3) attributed to d-d transition of $\mathrm{Cu}(\mathrm{II})\left(3 \mathrm{~d}^{9}\right)$ and the bands at around 340 and $315 \mathrm{~nm}$ (Fig. 3), related to oxygento-copper(II) charge transfer (CT) transitions involving framework oxygen and copper present in the zeolite structure as extra-framework octahedral $\mathrm{Cu}(\mathrm{II})$ and framework mononuclear $\mathrm{Cu}(\mathrm{II})$, respectively, in line with earlier reports [20,26,27].

According to DR UV-Vis results it may be concluded that for $\mathrm{C}-\mathrm{Cu}_{2.0} \mathrm{HAlBEA}$ catalyst copper predominantly occurred as octahedral $\mathrm{Cu}(\mathrm{II})$ species, whereas for $\mathrm{C}$ $\mathrm{Cu}_{2.0} \mathrm{SiBEA}$ mainly as isolated mononuclear $\mathrm{Cu}(\mathrm{II})$ species.

\subsubsection{Electron Paramagnetic Resonance spectroscopy}

The EPR spectrum of $\mathrm{Cu}_{2.0} \mathrm{HAlBEA}$ sample obtained at $298 \mathrm{~K}$ (Fig. 4) shows a broad, featureless and slightly anisotropic signal (axial symmetry). Due to its broadness, its $g_{\|}$and $g_{\perp}$ values can only be estimated. The averaged value of this signal $\left(\mathrm{g}_{\text {aver. }}=1 / 3\left(\mathrm{~g}_{\|}+2 \mathrm{~g}_{\perp}\right)=2.20\right)$ is close to that observed earlier [28-32] for hydrated octahedral $\mathrm{Cu}$ (II) species exhibiting rotational/mobility freedom or a quick change of the elongation axis. Upon cooling down to $77 \mathrm{~K}$, the EPR signal transforms to an axial one presenting hyperfine splitting $\left(\mathrm{A}_{\|}\right)($Fig. 5). The simulated EPR parameters (see Table 1) are very similar to those previously published for CuZSM-5 and Cu-BEA samples [29,32-35], and can be assigned to hydrated octahedral $\mathrm{Cu}$ (II) species for which the mobility/motion has been severely reduced at $77 \mathrm{~K}$.

As showed in Fig. 4, calcined C-Cu ${ }_{2.0} \mathrm{HAlBEA}$ sample exhibits at $298 \mathrm{~K}$ a similar EPR signature as that of $\mathrm{Cu}_{2.0}$ HAlBEA, with an additional weak signal (shoulder around $\mathrm{g}=$ 2.08 in Fig. 4) that may be assigned to hydrated octahedral immobilized $\mathrm{Cu}(\mathrm{II})$ species. Such immobilization could be explained by removal upon calcination of water ligands and formation strong $\mathrm{Cu}-\mathrm{O}_{\text {lattice }}$ bond. At $77 \mathrm{~K}$, the EPR spectrum is very similar to that obtained for $\mathrm{Cu}_{2.0} \mathrm{HAlBEA}$ but more intense and better resolved.

In the case of $\mathrm{Cu}_{2.0} \mathrm{SiBEA}$ sample, the EPR signal obtained at $298 \mathrm{~K}$ is featureless and isotropic ( $g_{\text {iso }}=2.19$ ) (Fig. 4), once again typical of hydrated octahedral $\mathrm{Cu}$ (II) species, but with a higher motional freedom than that observed for $\mathrm{Cu}_{2.0} \mathrm{HAlBEA}$. This is confirmed by 
the spectrum recorded at $77 \mathrm{~K}$ (Fig. 5) when a large portion of mobile hydrated octahedral $\mathrm{Cu}(\mathrm{II})$ species is still observed.

Upon calcination of $\mathrm{Cu}_{2.0} \mathrm{SiBEA}$ sample, the $\mathrm{Cu}(\mathrm{II})$ signals recorded for $\mathrm{C}$ $\mathrm{Cu}_{2.0}$ SiBEA at $298 \mathrm{~K}$ (Fig. 4) and $77 \mathrm{~K}$ (Fig. 5) decreased in intensity, pointing out that a big portion of copper species has become EPR silent. The remaining EPR signal correspond to hydrated octahedral $\mathrm{Cu}(\mathrm{II})$ species mainly immobilized or frozen with a small portion of mobile ones only present at $298 \mathrm{~K}$ (see Table 2 for EPR parameters). Such strong decrease of overall EPR signal intensity has been frequently reported in the literature for $\mathrm{Cu}$-containing zeolites, especially after outgassing/dehydration [28-30,36-38]. Three possible causes may explain such EPR intensity drop: (i) reduction of $\mathrm{Cu}$ (II) to diamagnetic $\mathrm{Cu}(\mathrm{I})$ species; (ii) formation of $\mathrm{Cu}(\mathrm{II})-\mathrm{O}-\mathrm{Cu}(\mathrm{II})$ species (O referring either to $\mathrm{O}_{2}{ }^{-}$or $\mathrm{OH}^{-}$) or (iii) transformation of octahedral $\mathrm{Cu}(\mathrm{II})$ species into lower coordinated $\mathrm{Cu}$ (II) ones, especially into slightly distorted $\mathrm{C}_{3 \mathrm{v}}$ trigonal symmetry. In the third case, such $\mathrm{Cu}$ (II) species present very close low lying excited states allowing for a very fast spin-lattice relaxation and resulting in large broadening and the associated loss in intensity of the EPR signal so that it may not be observable even at $77 \mathrm{~K}$.

As $\mathrm{Cu}_{2.0}$ SiBEA being calcined in air, the reduction of $\mathrm{Cu}(\mathrm{II})$ to $\mathrm{Cu}(\mathrm{I})$ species seems unlikely. Also, a good dispersion of $\mathrm{Cu}$ (II) species upon preparation of $\mathrm{Cu}_{2.0} \mathrm{SiBEA}$ by twostep postsynthesis method and the low $\mathrm{Cu}$ content may rule out the formation of $\mathrm{Cu}$ (II)-O$\mathrm{Cu}$ (II) species or magnetically interacting $\mathrm{Cu}(\mathrm{II})$ centers. A possible explanation of the strong decrease of the EPR signal intensity for $\mathrm{C}-\mathrm{Cu}_{2.0} \mathrm{SiBEA}$ sample would be the formation of a large amount of isolated and EPR-silent $\mathrm{Cu}(\mathrm{II})$ species with specific $\mathrm{C}_{3 \mathrm{v}}$ symmetry. Such species would result from the incorporation of copper in the framework of SiBEA zeolite by reaction with silanol groups of hydroxyl nests created during removal of aluminium from the zeolite upon acid nitric treatment.

\subsection{Acidity of Cu2.0HAIBEA and $\mathrm{Cu} 2.0 \mathrm{SiBEA}$ determined by FTIR+CO}

\subsubsection{FTIR + CO}

The FTIR spectroscopy following CO sorption as a probe molecule was applied in order to study the acidic centers present in both $\mathrm{Cu}_{2.0} \mathrm{HAlBEA}$ and $\mathrm{Cu}_{2.0} \mathrm{SiBEA}$ zeolites. It is well known that $\mathrm{CO}$ molecules are more strongly bonded with $\mathrm{Cu}^{+}$than $\mathrm{Cu}^{2+}$ ions, however at low temperature it is possible to observe in the FTIR spectra bands related to both $\mathrm{Cu}(\mathrm{I})$ and $\mathrm{Cu}(\mathrm{II})$ species. 
The adsorption of $\mathrm{CO}$ on $\mathrm{Cu}_{2.0} \mathrm{HAlBEA}$ zeolite led to appearance of bands at 2232 , 2223, 2201, 2195, 2188, 2173, 2169, 2152, 2141, 2131 and $2131 \mathrm{~cm}^{-1}$ (Fig. 6A). Intensity of all bands gradually increased with addition of following $\mathrm{CO}$ doses. The two bands with highest wavenumbers at 2232 and $2223 \mathrm{~cm}^{-1}$ are due to interaction of CO with framework and extra-framework $\mathrm{Al}(\mathrm{III})$ species, in agreement with earlier report on BEA zeolite [39]. The very intense band at $2173 \mathrm{~cm}^{-1}$ is related to the adsorption of $\mathrm{CO}$ on bridged $\mathrm{Si}-\mathrm{O}(\mathrm{H})-\mathrm{Al}$ groups possesses strong acidic character [40]. Ascription of remaining bands to particular species is not easy because of their similar wavenumber positions in infrared spectra. In the previous investigations of $\mathrm{Cu}$ containing materials it was reported that mononuclear $\mathrm{Cu}(\mathrm{I})$ species might form with carbon monoxide mono-, di- and tricarbolyls moieties depending of temperature, $\mathrm{CO}$ pressure and environment of copper centers [41-44]. In the spectrum of $\mathrm{Cu}_{2.0}$ HAlBEA the bands at 2152 and $2188 \mathrm{~cm}^{-1}$ may correspond to $\mathrm{Cu}^{+}(\mathrm{CO})_{2}$ species and bands at $2195,2169,2141 \mathrm{~cm}^{-1}$ may be ascribed to $\mathrm{Cu}^{+}(\mathrm{CO})_{3}$ species present in cationic positions consistent with similar observations of Bordiga et al. and Lamberti et al. [41,45]. Moreover, the high intensity of band at $2169 \mathrm{~cm}^{-1}$ may result from overlapping the band related to copper species by band related to $\mathrm{SiO}-\mathrm{H}$ [46] which presence cannot be excluded. In line with recent studies [37,41], band at $2201 \mathrm{~cm}^{-1}$ represent $\mathrm{Cu}$ (II)-CO adducts, where $\mathrm{CO}$ is adsorbed on isolated copper (II) species. Gora-Marek et al. [47] indicated appearance of $2122 \mathrm{~cm}^{-1}$ bands as a result of weak $\mathrm{Cu}(0)-\mathrm{CO}$ interactions, however due to the application of the oxidative atmosphere for sample pre-treatment we rather opted for Giordanino et al. [48] explanation, in which they attributed this band to interaction of $\mathrm{CO}$ with extra-framework $\mathrm{Cu}(\mathrm{I})$ species.

After introduction of $\mathrm{CO}$ up to $133.3 \mathrm{~Pa}$ (equilibrium pressure) gradual evacuation was performed as showed in Figure 6B. It can be seen that the evacuation led to complete disappearance of the bands at 2193, 2173, 2169, 2140 and $2136 \mathrm{~cm}^{-1}$ and a sharp decrease in the intensity of the bands at 2233, 2224, and $2200 \mathrm{~cm}^{-1}$. Furthermore, at low CO coverage (inset Fig. 5B) the band at $2183 \mathrm{~cm}^{-1}$ became clearly visible and the band at $2152 \mathrm{~cm}^{-1}$ strongly developed during evacuation suggesting a transformation of tricarbonyl into dicarbonyl species, in line with earlier report [41]. It is important to stress that the $\mathrm{Cu}$ (II)-CO adducts were present even after the deep evacuation indicating considerable acidic character of $\mathrm{Cu}(\mathrm{II})$ species.

FTIR spectra of $\mathrm{Cu}_{2.0}$ SiBEA zeolite after adsorption of $\mathrm{CO}$ exhibit nine bands (Fig. 7A). The most intense one at $2202 \mathrm{~cm}^{-1}$ is due to presence of isolated mononuclear copper(II) species, whereas bands at 2189,2168 and $2140 \mathrm{~cm}^{-1}$ are related to $\mathrm{Cu}^{+}(\mathrm{CO})_{3}$ species in 
agreement with literature data [45]. Moreover the bands at 2129 and $2135 \mathrm{~cm}^{-1}$ are ascribed to copper(I) oxo-species in line with earlier reports on copper containing materials [49]. The bands at 2175,2163 and $2161 \mathrm{~cm}^{-1}$ are related to acidic bridging hydroxyls, internal and external silanol groups, respectively, in line with earlier studies [40,46].

Upon evacuation, it was observed complete disappearance of the bands related to hydroxyls groups and tricarbonyls species. Simultaneously, the band at $2151 \mathrm{~cm}^{-1}$, typical for $\mathrm{Cu}(\mathrm{I})-(\mathrm{CO})_{2}$, appeared. Additionally, the band at $2135 \mathrm{~cm}^{-1}$, which corresponds to relatively stable interaction between $\mathrm{CO}$ and $\mathrm{Cu}(\mathrm{I})$ of extra-framework copper compounds, was shifted to $2141 \mathrm{~cm}^{-1}$. These results suggest similar interaction strength of $\mathrm{Cu}(\mathrm{II})$ and $\mathrm{Cu}(\mathrm{I})$ species with $\mathrm{CO}$ in $\mathrm{Cu}_{2.0} \mathrm{SiBEA}$. The significant intensity of the band at $2205 \mathrm{~cm}^{-1}$ after evacuation (inset Fig. 7B) may be due to stable and strong interaction between $\mathrm{CO}$ sorption on isolated framework $\mathrm{Cu}$ (II) species. Furthermore, for both studied zeolite the bond at $2157 \mathrm{~cm}^{-1}$, related to the monocarbonyl species [43] which normally form after $\mathrm{CO}$ adsorption on isolated $\mathrm{Cu}^{+}$, was not observed even after deep evacuation.

To sum up it may be said that in $\mathrm{Cu}_{2.0}$ SiBEA and $\mathrm{Cu}_{2.0}$ HAlBEA zeolite occur alternative copper species - mostly copper ions in the cationic positions for $\mathrm{Cu}_{2.0} \mathrm{HAlBEA}$ zeolite and predominantly mononuclear framework $\mathrm{Cu}$ (II) species for $\mathrm{Cu}_{2.0} \mathrm{SiBEA}$ zeolite.

\subsubsection{FTIR + Pyridine}

To precisely calculate concentration of acidic sites in supports and copper containing catalysts the FTIR experiments with pyridine adsorption were carried out for all studied samples. The results obtained after pyridine desorption at $423 \mathrm{~K}$ were summarized and compared in Table 3.

As we have recently evidenced [13], SiBEA contains very small amount of the Brønsted and Lewis acidic centers due to presence of traces of aluminum species remaining after nitric acid treatment. After the introduction of copper into SiBEA an increase in the number of Lewis acidic centers was observed (form 3 to $52 \mu \mathrm{mol} \mathrm{g}^{-1}$ ), probably due to formation of isolated, framework copper(II) species. No formation of an additional amount of the Bronsted acidic sites was reported.

On the other hand, HAlBEA and $\mathrm{Cu}_{2.0}$ HAlBEA zeolites contained a large amount of acidic sites. However, after impregnation of HAlBEA support with the copper precursor the number of strong Bronsted sites decreased with simultaneous increase in amount of Lewis centers (Table 3). This effect was a result of partial exchange between $\mathrm{Cu}^{2+}$ and $\mathrm{H}^{+}$ions at the 
cationic positions in BEA zeolite cavities. Thus, copper occurring in extra-framework positions resulted in formation of additional amount of Lewis acidic centers.

\subsection{Reducibility of copper determined by TPR of $\mathbf{H}_{2}$}

TPR experiments were carried out to distinguish reducibility of different copper species present in $\mathrm{C}-\mathrm{Cu}_{2.0} \mathrm{HAlBEA}$ and $\mathrm{C}-\mathrm{Cu}_{2.0} \mathrm{SiBEA}$ samples. Figure 8 exhibits TPR patterns of copper containing zeolites beta prepared with two different methods. TPR pattern of C$\mathrm{Cu}_{2.0} \mathrm{HAlBEA}$ exhibits quite broad two peaks at 535 and $690 \mathrm{~K}$ probably related to two steps reduction of copper (II) species, firstly from $\mathrm{Cu}$ (II) to $\mathrm{Cu}$ (I), and secondly from $\mathrm{Cu}$ (I) to metallic copper. Similar TPR results were observed for many other copper containing zeolites like $\mathrm{Cu} / \mathrm{SAPO}-5, \mathrm{Cu}-\mathrm{Beta}$ and $\mathrm{Cu}-\mathrm{MFI}$ [50-52]. However, broad character of both peaks may indicate presence of different copper species, not only mononuclear $\mathrm{Cu}$ (II) species but also more complex polynuclear $\mathrm{Cu}(\mathrm{II})$ species [43].

The TPR pattern of $\mathrm{C}-\mathrm{Cu}_{2.0} \mathrm{SiBEA}$ was significantly different compare to the pattern of $\mathrm{C}-\mathrm{Cu}_{2.0} \mathrm{HAlBEA}$. It exhibits narrow peak at $490 \mathrm{~K}$ with a small shoulder at $465 \mathrm{~K}$ and additional low intense peak at $585 \mathrm{~K}$. The signals at 465 and $490 \mathrm{~K}$ probably correspond to the reduction of $\mathrm{Cu}(\mathrm{II})$ to $\mathrm{Cu}(\mathrm{I})$ of two types mononuclear, framework copper species. The presence of two types of copper framework species is related to the appearance of two types of aluminum framework in the parent BEA zeolite $[13,53]$.

The low intense peak with a maximum at $585 \mathrm{~K}$ may arise from the partial reduction of $\mathrm{Cu}(\mathrm{I})$ species to $\mathrm{Cu}(0)$. Low integral area of this signal may suggest that the reduction of $\mathrm{Cu}(\mathrm{I})$ species to metallic form was not complete, as a result of a strong interaction between SiBEA support and copper.

In order to confirm this statement, it was done the quantitative analysis of TPR results. As shown in Table 4 copper in $\mathrm{C}-\mathrm{Cu}_{2.0} \mathrm{HAlBEA}$ was completely reduced whereas for C$\mathrm{Cu}_{2.0}$ SiBEA only $65 \%$ of $\mathrm{Cu}$ (II) reduction was achieved. It indicates that copper(II) in former catalyst reduces easier to metallic form. On the other hand, copper(II) species in C$\mathrm{Cu}_{2.0} \mathrm{SiBEA}$ are stronger coupled to the SiBEA matrix and they may remain as $\mathrm{Cu}(\mathrm{I})$ species in large contribution even after reduction at high temperature. Thus, these facts prove different nature and properties of copper species in the framework and extra-framework positions. 


\subsection{Catalytic activity of Cu2.0HAIBEA and Cu2.0SiBEA catalysts}

In some of the previous reports [20,54-57] it was mentioned that in NO abatement reactions such as NO decomposition and HC-SCR of NO, the active centers were copper species present in zeolites cationic positions. The authors suggested that presence of aluminum in the zeolites framework is required in order to obtain active and high selective catalysts. Moreover, in the recent works on the most promising $\mathrm{NH}_{3}-\mathrm{SCR}$ catalysts $(\mathrm{Cu}-\mathrm{SSZ}$ and $\mathrm{Cu}-\mathrm{SAPO}-34)$ it was indicated that $\mathrm{Cu}(\mathrm{II})$ species localized at 6-MR position of $\mathrm{CHA}$ structure and coordinated with two framework Al atoms are the most effective catalytic sites in NO reduction with ammonia [58-60].

After careful analysis of physicochemical properties of $\mathrm{Cu}_{2.0} \mathrm{HAlBEA}$ and $\mathrm{Cu}_{2.0} \mathrm{SiBEA}$ zeolites the catalytic tests of SCR of NO with ammonia were carried out to investigate the influence of preparation procedures on the catalysts activity and selectivity in DeNOx process. Moreover, the aim of our work was to compare behavior of extra-framework octahedral $\mathrm{Cu}(\mathrm{II})$ species predominantly present in $\mathrm{Cu}_{2.0} \mathrm{HAlBEA}$ with isolated framework mononuclear $\mathrm{Cu}(\mathrm{II})$ species occurring mainly in $\mathrm{Cu}_{2.0} \mathrm{SiBEA}$.

Figure 9 exhibits the $\mathrm{NO}$ conversion in $\mathrm{NH}_{3}-\mathrm{SCR}$ on $\mathrm{Cu}_{2.0} \mathrm{HAlBEA}$ and $\mathrm{Cu}_{2.0} \mathrm{SiBEA}$ catalysts. At the low temperature range both catalysts gave almost the same NO conversion ( $\sim 60 \%$ at $423 \mathrm{~K}$ and $\sim 95 \%$ at $472 \mathrm{~K}$ ). However, when the reaction temperature started to increase gradual decrease in the NO conversion was observed for $\mathrm{Cu}_{2.0} \mathrm{SiBEA}$, whereas for $\mathrm{Cu}_{2.0}$ HAlBEA the activity remained very high (almost $100 \%$ of NO conversion) up to $573 \mathrm{~K}$. Although in the higher temperature range both catalysts lost some activity. For $\mathrm{Cu}_{2.0} \mathrm{SiBEA}$ decrease in the catalytic activity was more significant than for $\mathrm{Cu}_{2.0}$ HAlBEA (around 15 and $20 \%$ lower NO conversion at 723 and $773 \mathrm{~K}$ for $\mathrm{Cu}_{2.0}$ SiBEA than for $\mathrm{Cu}_{2.0}$ HAlBEA, respectively).

Furthermore, the $\mathrm{N}_{2}$ selectivity (Fig. 10) was high for both catalysts in the whole temperature range. Slightly decrease in the selectivity toward $\mathrm{N}_{2}$ with increasing reaction temperature was observed from 573 to $723 \mathrm{~K}$. The $\mathrm{N}_{2}$ selectivity did not drop to less that 90 $\%$ at any studied temperature. However, for $\mathrm{Cu}_{2.0} \mathrm{HAlBEA}$ it was slightly higher than for $\mathrm{Cu}_{2.0} \mathrm{SiBEA}$. In case of $\mathrm{Cu}_{2.0} \mathrm{HAlBEA}$ particular performance was observed at $423-573 \mathrm{~K}$, when the $\mathrm{N}_{2}$ selectivity was around $100 \%$. A small drop in selectivity toward $\mathrm{N}_{2}$ might result from the presence of competitive reactions of the ammonia oxidation to $\mathrm{NO}$ and/or $\mathrm{N}_{2} \mathrm{O}$. $\mathrm{NH}_{3}$ oxidation is especially strongly promoted by octahedral $\mathrm{Cu}$ (II) species at the high temperature range, in agreement with earlier works on the application of copper containing zeolites for $\mathrm{NH}_{3}$-SCR process $[61,62]$. 
The better catalytic properties of $\mathrm{Cu}_{2.0} \mathrm{HAlBEA}$ than $\mathrm{Cu}_{2.0} \mathrm{SiBEA}$ may suggest that the vicinity of $\mathrm{Al}$ species improved catalytic activity of copper species leading to a bit higher activity and selectivity. However, the presence of aluminum in the framework is not necessary to obtain the efficient zeolite catalyst for NO removal, as it is showed by very high activity of $\mathrm{Cu}_{2.0}$ SiBEA. A slightly higher activity of $\mathrm{Cu}_{2.0}$ HAlBEA than $\mathrm{Cu}_{2.0}$ SiBEA at might be related to the presence in former much higher amount of strong Brønsted and Lewis acidic sites which may play important role in SCR mechanism according to the reports of Eng and Bartholomew [63] and Stevenson et al. [64]. As we described previously HAlBEA support contains a large amount of acidic centers, whereas SiBEA support possesses only a very little amount of acidic centers, as reported earlier [65].

The catalysts stability and activity in the presence of water steam in substrates stream were also studied. The results showed in Figure S1 indicate that presence of water resulted in lower NO conversion, however catalyst stability remained high even after three catalytic cycles. More results about catalyst stability and comparison of our catalysts activity with literature data may be found in supportive information to this article (Table S1).

\section{Conclusions}

Modifications of zeolite beta by two different methods led to obtaining two types of catalysts with considerable different nature and environment of copper species.

Copper species in $\mathrm{Cu}_{2.0}$ HAlBEA zeolite, prepared with conventional wet impregnation method, were predominantly present as extra-framework octahedral $\mathrm{Cu}$ (II) species, whereas copper species in $\mathrm{Cu}_{2.0}$ SiBEA zeolite, obtained by two-step postsynthesis method, occurred mostly as framework mononuclear $\mathrm{Cu}(\mathrm{II})$ species.

Both $\mathrm{Cu}_{2.0}$ SiBEA and $\mathrm{Cu}_{2.0} \mathrm{HAlBEA}$ zeolite catalysts showed a very high activity in this reaction with NO conversion higher than $80 \%$ and $\mathrm{N}_{2}$ selectivity higher than $95 \%$ in the temperature range between 473 and $623 \mathrm{~K}$.

However, catalyst prepared with conventional wet impregnation method gave better activity in NO conversion and $\mathrm{N}_{2}$ selectivity in SCR of NO with ammonia at the high temperature range suggesting a positive effect of the aluminum atoms on catalyst performance in SCR of NO. Thus, it shown that the state of copper species as well as the acidity plays an important role in SCR of NO process. 


\section{Acknowledgements}

This project was funded by the National Science Center "PRELUDIUM" UMO2012/07/N/ST5/00171 (R.B., S.D.). Special thanks to DSc Ireneusz Kocemba for help with carrying out TPR experiments and for Laetitia Valentin for acidity measurement on $\mathrm{Cu}_{2.0} \mathrm{HAlBEA}$ by FTIR of pyridine adsorption.

\section{References}

[1] N. Wilken, K. Wijayanti, K. Kamasamudram, N.W. Currier, R. Vedaiyan, A. Yezerets, L. Olsson, Appl. Catal. B Environ. 111-112 (2012) 58-66.

[2] O. Mihai, C.R. Widyastuti, S. Andonova, K. Kamasamudram, J. Li, S.Y. Joshi, N.W. Currier, A. Yezerets, L. Olsson, J. Catal. 311 (2014) 170-181.

[3] A. Corma, A. Palomares, F. Marquez, J. Catal. 139 (1997) 132-139.

[4] S. Yashnik, Z. Ismagilov, Appl. Catal. B Environ. 170-171 (2015) 241-254.

[5] I. Lezcano-Gonzalez, U. Deka, H.E. van der Bij, P. Paalanen, B. Arstad, B.M. Weckhuysen, A.M. Beale, Appl. Catal. B Environ. 154-155 (2014) 339-349.

[6] L. Ma, Y. Cheng, G. Cavataio, R.W. McCabe, L. Fu, J. Li, Chem. Eng. J. 225 (2013) $323-330$.

[7] A. Shishkin, H. Kannisto, P.-A. Carlsson, H. Härelind, M. Skoglundh, Catal. Sci. Technol. 4 (2014) 3917-3926.

[8] J.H. Kwak, R.G. Tonkyn, D.H. Kim, J. Szanyi, C.H.F. Peden, J. Catal. 275 (2010) $187-190$.

[9] R. Martínez-Franco, M. Moliner, P. Concepcion, J.R. Thogersen, A. Corma, J. Catal. 314 (2014) 73-82.

[10] S. Dzwigaj, M. Matsuoka, R. Franck, M. Anpo, M. Che, J. Phys. Chem. B 102 (1998) 6309-6312.

[11] S. Dzwigaj, M. Che, J. Phys. Chem. B 110 (2006) 12490-3.

[12] S. Dzwigaj, T. Shishido, J. Phys. Chem. C 112 (2008) 5803-5809.

[13] R. Baran, Y. Millot, T. Onfroy, J.M. Krafft, S. Dzwigaj, Microporous Mesoporous Mater. 163 (2012) 122-130. 
[14] T. Spałek, P. Pietrzyk, Z. Sojka, J. Chem. Inf. Model. 45 (2005) 18-29.

[15] A. Śrebowata, R. Baran, D. Łomot, D. Lisovytskiy, T. Onfroy, S. Dzwigaj, Appl. Catal. B Environ. 147 (2014) 208-220.

[16] S. Dzwigaj, J. Janas, J. Gurgul, R.P. Socha, T. Shishido, M. Che, Appl. Catal. B Environ. 85 (2009) 131-138.

[17] J. Janas, J. Gurgul, R.P. Socha, S. Dzwigaj, Appl. Catal. B Environ. 91 (2009) 217224.

[18] R. Baran, F. Averseng, Y. Millot, T. Onfroy, S. Casale, S. Dzwigaj, J. Phys. Chem. C 118 (2014) 4143-4150.

[19] S. Dzwigaj, P. Massiani, A. Davidson, M. Che, J. Mol. Catal. A Chem. 155 (2000) $169-182$.

[20] G. Moretti, C. Dossi, A. Fusi, S. Recchia, R. Psaro, Appl. Catal. B Environ. 20 (1999) $67-73$.

[21] M.H. Groothaert, P.J. Smeets, B.F. Sels, P. a. Jacobs, R. a. Schoonheydt, J. Am. Chem. Soc. 127 (2005) 1394-1395.

[22] H. Praliaud, S. Mikhailenko, Z. Chajar, M. Primet, Appl. Catal. B Environ. 16 (1998) $359-374$.

[23] I. Lezcano-Gonzalez, U. Deka, H.E. van der Bij, P. Paalanen, B. Arstad, B.M. Weckhuysen, a. M. Beale, Appl. Catal. B Environ. 154-155 (2014) 339-349.

[24] K.I. Shimizu, R. Maruyama, T. Hatamachi, T. Kodama, J. Phys. Chem. C 111 (2007) 6440-6446.

[25] E.I. Solomon, P. Chen, M. Metz, S.-K. Lee, A.E. Palmer, Angew. Chemie Int. Ed. 40 (2001) 4570-4590.

[26] M.H. Groothaert, J. a. Van Bokhoven, A. a. Battiston, B.M. Weckhuysen, R. a. Schoonheydt, J. Am. Chem. Soc. 125 (2003) 7629-7640.

[27] S. Dzwigaj, J. Janas, J. Mizera, J. Gurgul, R.P. Socha, M. Che, Catal. Letters 126 (2008) 36-42.

[28] A. Godiksen, F.N. Stappen, P.N.R. Vennestrøm, F. Giordanino, S.B. Rasmussen, L.F. Lundegaard, S. Mossin, J. Phys. Chem. C 118 (2014) 23126-23138.

[29] J. Soria, a. Martinez-Arias, a. Martinez-Chaparro, J.C. Conesa, Z. Schay, J. Catal. 190 
(2000) 352-363.

[30] S.C. Larsen, A. Aylor, A.T. Bell, J. a. Reimer, J. Phys. Chem. 98 (1994) 11533-11540.

[31] C.E. Sass, L. Kevan, J. Phys. Chem. 92 (1988) 14-15.

[32] P.J. Carl, S.C. Larsen, J. Catal. 218 (1999) 208-218.

[33] A. V Kucherov, A.N. Shigapov, A.A. Ivanov, M. Shelef, J. Catal. 186 (1999) 334-344.

[34] A. Murali, Z. Chang, K.T. Ranjit, R.M. Krishna, V. Kurshev, L. Kevan, J. Phys. Chem. B 106 (2002) 6913-6920.

[35] a. . Kucherov, H.. Karge, R. Schlögl, Microporous Mesoporous Mater. 25 (1998) 714.

[36] J.C. Conesa, J. Soria, J. Phys. Chem. 82 (1978) 1575-1578.

[37] G.T. Palomino, P. Fisicaro, S. Bordiga, a Zecchina, E. Giamello, C. Lamberti, J. Phys. Chem. B 104 (2000) 4064-4073.

[38] M. Lo Jacono, G. Fierro, R. Dragone, C.N.R. Sacso, D. Chimica, V. Uni, L. Sapienza, P.A. Moro, X. Feng, J. Itri, W.K. Hall, J. Phys. Chem. B 101 (1997) 1979-1984.

[39] K. Hadjiivanov, A. Penkova, R. Kefirov, S. Dzwigaj, M. Che, Microporous Mesoporous Mater. 124 (2009) 59-69.

[40] S. Mintova, V. Valtchev, T. Onfroy, C. Marichal, H. Knözinger, T. Bein, Microporous Mesoporous Mater. 90 (2006) 237-245.

[41] C. Lamberti, A. Zecchina, E. Groppo, S. Bordiga, Chem. Soc. Rev. 39 (2010) 49515001.

[42] J. Szanyi, J.H. Kwak, H. Zhu, C.H.F. Peden, Phys. Chem. Chem. Phys. 15 (2013) $2368-80$.

[43] R. Kefirov, A. Penkova, K. Hadjiivanov, S. Dzwigaj, M. Che, Microporous Mesoporous Mater. 116 (2008) 180-187.

[44] K. Frolich, R. Bulánek, E. Frýdová, Microporous Mesoporous Mater. 186 (2014) 3745.

[45] S. Bordiga, C. Pazé, G. Berlier, D. Scarano, G. Spoto, a. Zecchina, C. Lamberti, Catal. Today 70 (2001) 91-105.

[46] K. Hadjiivanov, E. Ivanova, R. Kefirov, J. Janas, A. Plesniar, S. Dzwigaj, M. Che, Microporous Mesoporous Mater. 131 (2010) 1-12. 
[47] K. Góra-Marek, a. E. Palomares, a. Glanowska, K. Sadowska, J. Datka, Microporous Mesoporous Mater. 162 (2012) 175-180.

[48] F. Giordanino, P.N.R. Vennestrøm, L.F. Lundegaard, F.N. Stappen, S. Mossin, P. Beato, S. Bordiga, C. Lamberti, Dalt. Trans. 42 (2013) 12741-61.

[49] L. Xu, C. Shi, Z. Zhang, H. Gies, F.S. Xiao, D. De Vos, T. Yokoi, X. Bao, M. Feyen, S. Maurer, B. Yilmaz, U. Müller, W. Zhang, Microporous Mesoporous Mater. 200 (2014) 304-310.

[50] D.L. Hoang, T.T.H. Dang, J. Engeldinger, M. Schneider, J. Radnik, M. Richter, A. Martin, J. Solid State Chem. 184 (2011) 1915-1923.

[51] L. Xu, C. Shi, Z. Zhang, H. Gies, F.S. Xiao, D. De Vos, T. Yokoi, X. Bao, M. Feyen, S. Maurer, B. Yilmaz, U. Müller, W. Zhang, Microporous Mesoporous Mater. (2014).

[52] R. Bulánek, B. Wichterlová, Z. Sobal, J. Tichý, Appl. Catal. B Environ. 31 (2001) 1325.

[53] R. Hajjar, Y. Millot, P.P. Man, M. Che, S. Dzwigaj, J. Phys. Chem. C 112 (2008) 20167-20175.

[54] J. Dědeček, B. Wichterlová, Phys. Chem. Chem. Phys. 1 (1999) 629-637.

[55] G. Moretti, Catal. Letters 28 (1994) 143-152.

[56] J. Dědeček, L. Čapek, B. Wichterlová, Appl. Catal. A Gen. 307 (2006) 156-164.

[57] B. Modén, P. Da Costa, D.K. Lee, E. Iglesia, J. Phys. Chem. B 106 (2002) 9633-9641.

[58] C. Paolucci, A.A. Verma, S.A. Bates, V.F. Kispersky, J.T. Miller, R. Gounder, W.N. Delgass, F.H. Ribeiro, W.F. Schneider, Angew. Chemie Int. Ed. 53 (2014) 1182811833.

[59] R. Martínez-Franco, M. Moliner, C. Franch, A. Kustov, A. Corma, Appl. Catal. B Environ. 127 (2012) 273-280.

[60] J. Wang, T. Yu, X. Wang, G. Qi, J. Xue, M. Shen, W. Li, Appl. Catal. B Environ. 127 (2012) 137-147.

[61] D. Wang, L. Zhang, J. Li, K. Kamasamudram, W.S. Epling, Catal. Today 231 (2014) 64-74.

[62] O. Mihai, C.R. Widyastuti, S. Andonova, K. Kamasamudram, J. Li, S.Y. Joshi, N.W. Currier, A. Yezerets, L. Olsson, J. Catal. 311 (2014) 170-181. 
[63] J. Eng, C.H. Bartholomew, J. Catal. 171 (1997) 27-44.

[64] S.A. Stevenson, J.C. Vartuli, C.F. Brooks, J. Catal. 239 (2000) 228-239.

[65] R. Baran, T. Onfroy, S. Casale, S. Dzwigaj, J. Phys. Chem. C 118 (2014) 2044520451. 


\section{Figure Captions}

Figure 1. XRD patterns recorded at room temperature of TEABEA, HAlBEA, $\mathrm{Cu}_{2.0} \mathrm{HAlBEA}$, spent- $\mathrm{Cu}_{2.0} \mathrm{HAlBEA}, \mathrm{SiBEA}, \mathrm{Cu}_{2.0} \mathrm{SiBEA}$ and spent- $\mathrm{Cu}_{2.0} \mathrm{SiBEA}$.

Figure 2. FTIR spectra of HAlBEA, $\mathrm{Cu}_{2.0} \mathrm{HAlBEA}$, SiBEA and $\mathrm{Cu}_{2.0} \mathrm{SiBEA}$ in the $\mathrm{OH}$ groups range.

Figure 3. DR UV-vis spectra recorded at room temperature of $\mathrm{Cu}_{2.0} \mathrm{HAlBEA}, \mathrm{Cu}_{2.0} \mathrm{SiBEA}, \mathrm{C}$ $\mathrm{Cu}_{2.0} \mathrm{HAlBEA}$ and $\mathrm{C}-\mathrm{Cu}_{2.0} \mathrm{SiBEA}$.

Figure 4. EPR spectra $(298 \mathrm{~K})$ of $\mathrm{Cu}_{2.0} \mathrm{HAlBEA}$ and $\mathrm{Cu}_{2.0} \mathrm{SiBEA}$ as synthesized then after calcination.

Figure 5. EPR spectra $(77 \mathrm{~K})$ of $\mathrm{Cu}_{2.0} \mathrm{HAlBEA}$ and $\mathrm{Cu}_{2.0} \mathrm{SiBEA}$ as synthesized then after calcination.

Figure 6. FTIR difference spectra in carbonyl stretching regions of $\mathrm{Cu}_{2.0} \mathrm{HAlBEA}$ (A) after adsorption of a small dose (ca. $10 \mu \mathrm{mol} \mathrm{g} \mathrm{g}^{-1}$ (a-d) then $45 \mu \mathrm{mol} \mathrm{g}^{-1}$ (e-f) of CO at $100 \mathrm{~K}$ and (B) evolution of the spectra in dynamic vacuum at $100 \mathrm{~K}(\mathrm{a}-\mathrm{g})$.

Figure 7. FTIR difference spectra in carbonyl stretching regions of $\mathrm{Cu}_{2.0} \mathrm{SiBEA}$ (A) after adsorption of a small dose (ca. $10 \mu \mathrm{mol} \mathrm{g} \mathrm{g}^{-1}$ (a-d) then $45 \mu \mathrm{mol} \mathrm{g}^{-1}$ (e-f) of CO at $100 \mathrm{~K}$ and (B) evolution of the spectra in dynamic vacuum at $100 \mathrm{~K}(\mathrm{a}-\mathrm{g})$.

Figure 8. TPR patterns of C-Cu $2.0 \mathrm{SiBEA}$ and $\mathrm{C}-\mathrm{Cu}_{2.0} \mathrm{HAlBEA}$.

Figure 9. $\mathrm{NO}$ conversion in $\mathrm{SCR}$ of $\mathrm{NO}$ with $\mathrm{NH}_{3}$ on $\mathrm{Cu}_{2.0} \mathrm{SiBEA}$ and $\mathrm{Cu}_{2.0} \mathrm{HAlBEA}$.

Figure 10. $\mathrm{N}_{2}$ selectivity in $\mathrm{SCR}$ of $\mathrm{NO}$ with $\mathrm{NH}_{3}$ on $\mathrm{Cu}_{2.0} \mathrm{SiBEA}$ and $\mathrm{Cu}_{2.0} \mathrm{HAlBEA}$. 


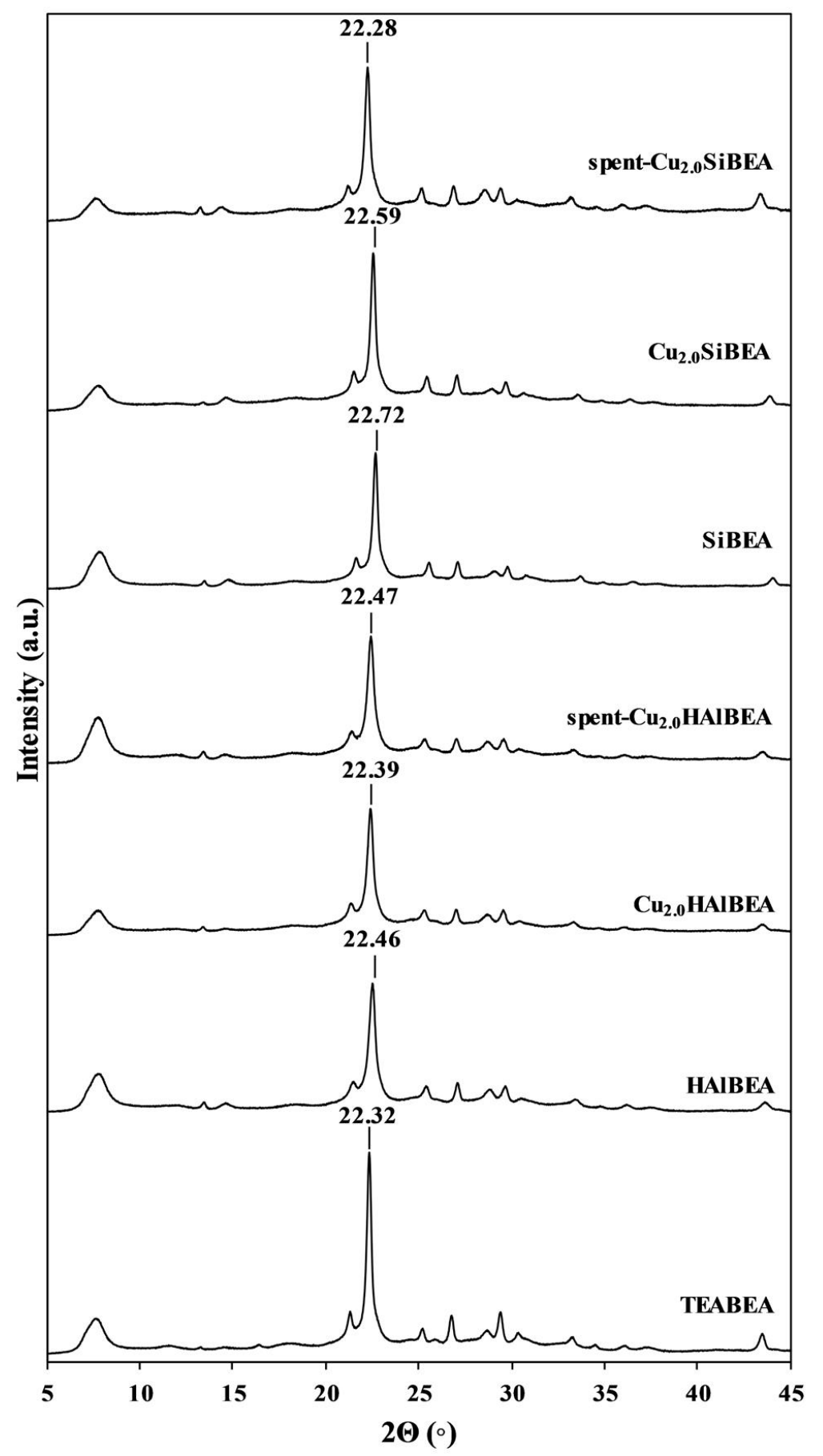

Figure 1 


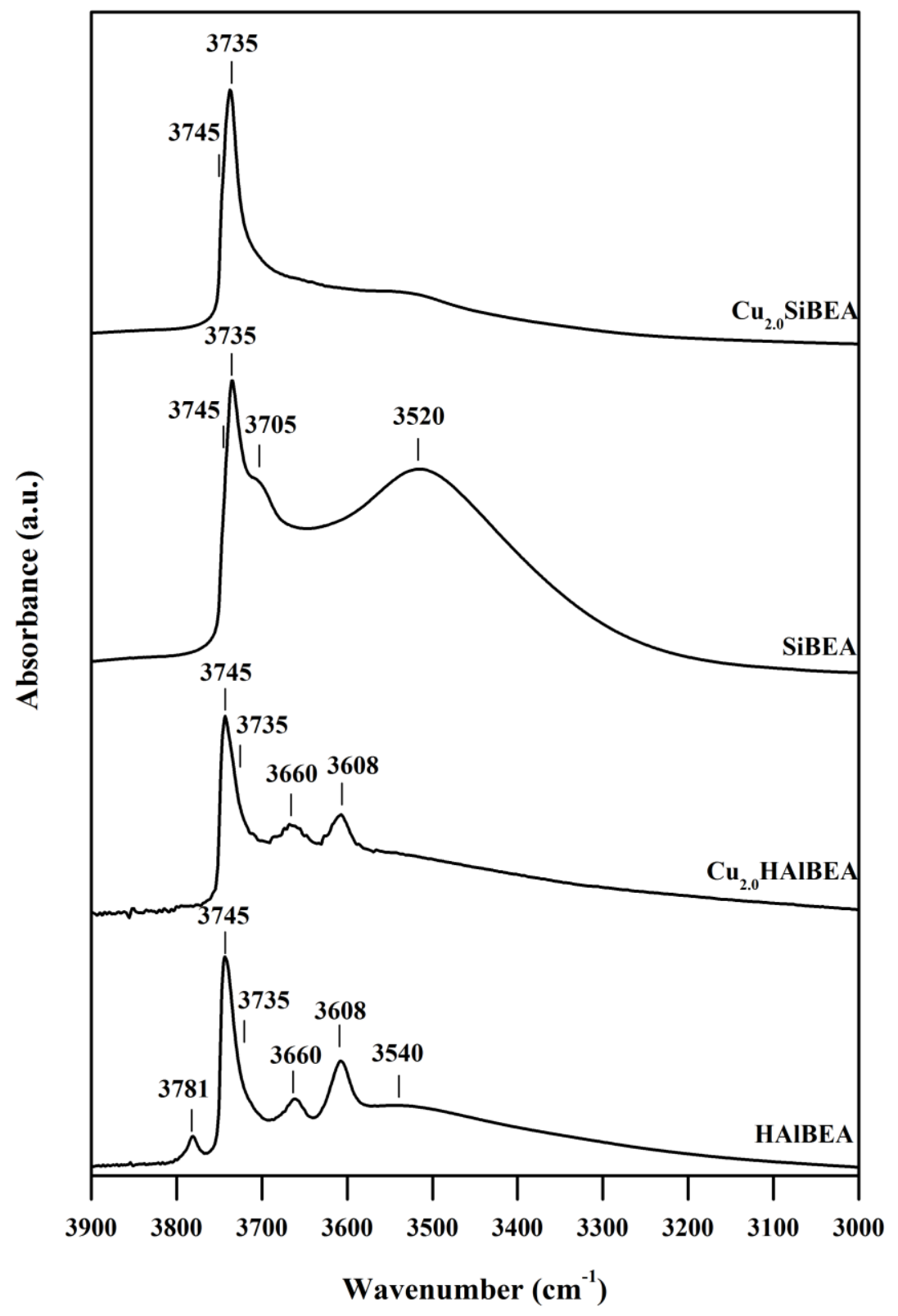

Figure 2 


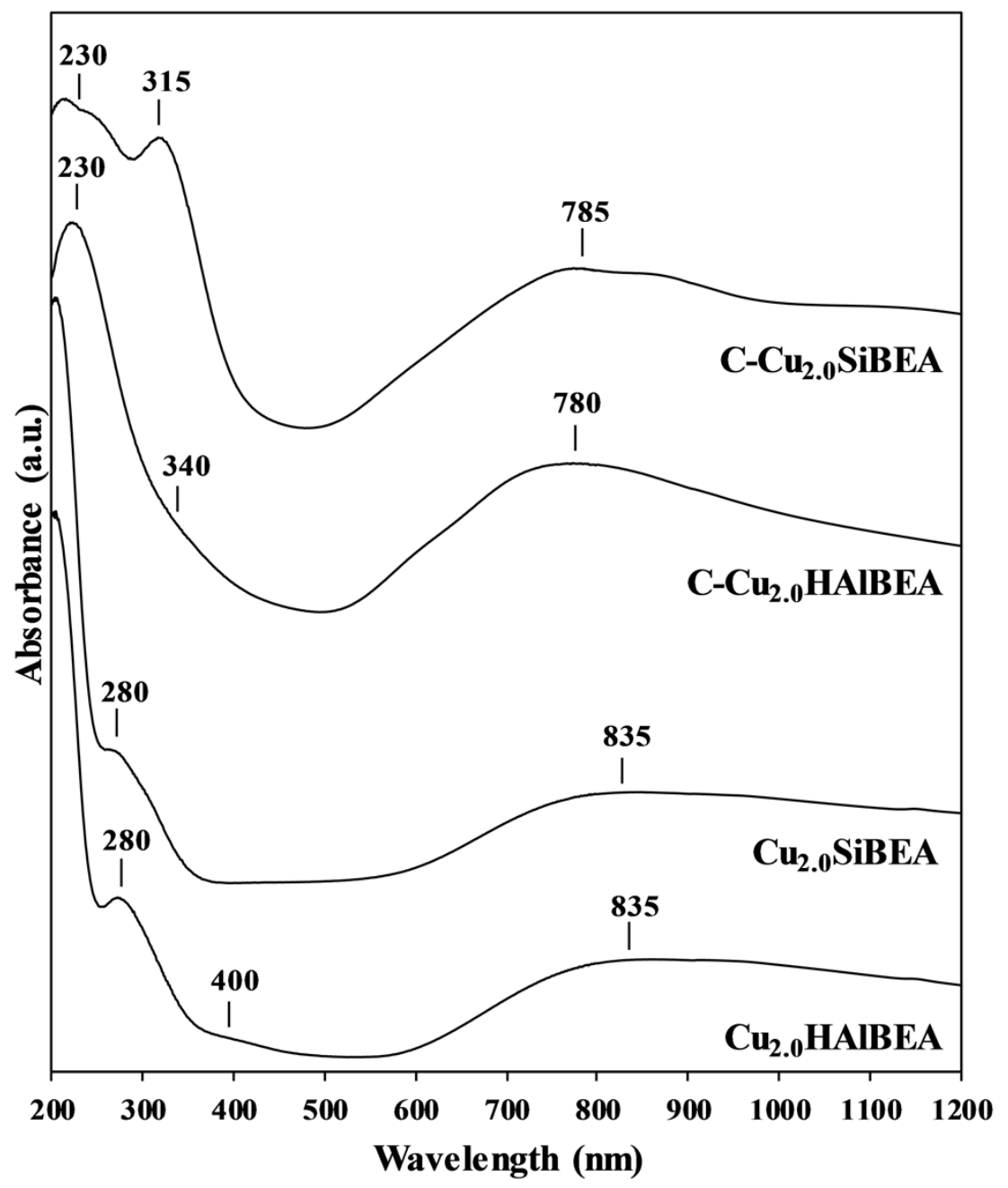

Figure 3 


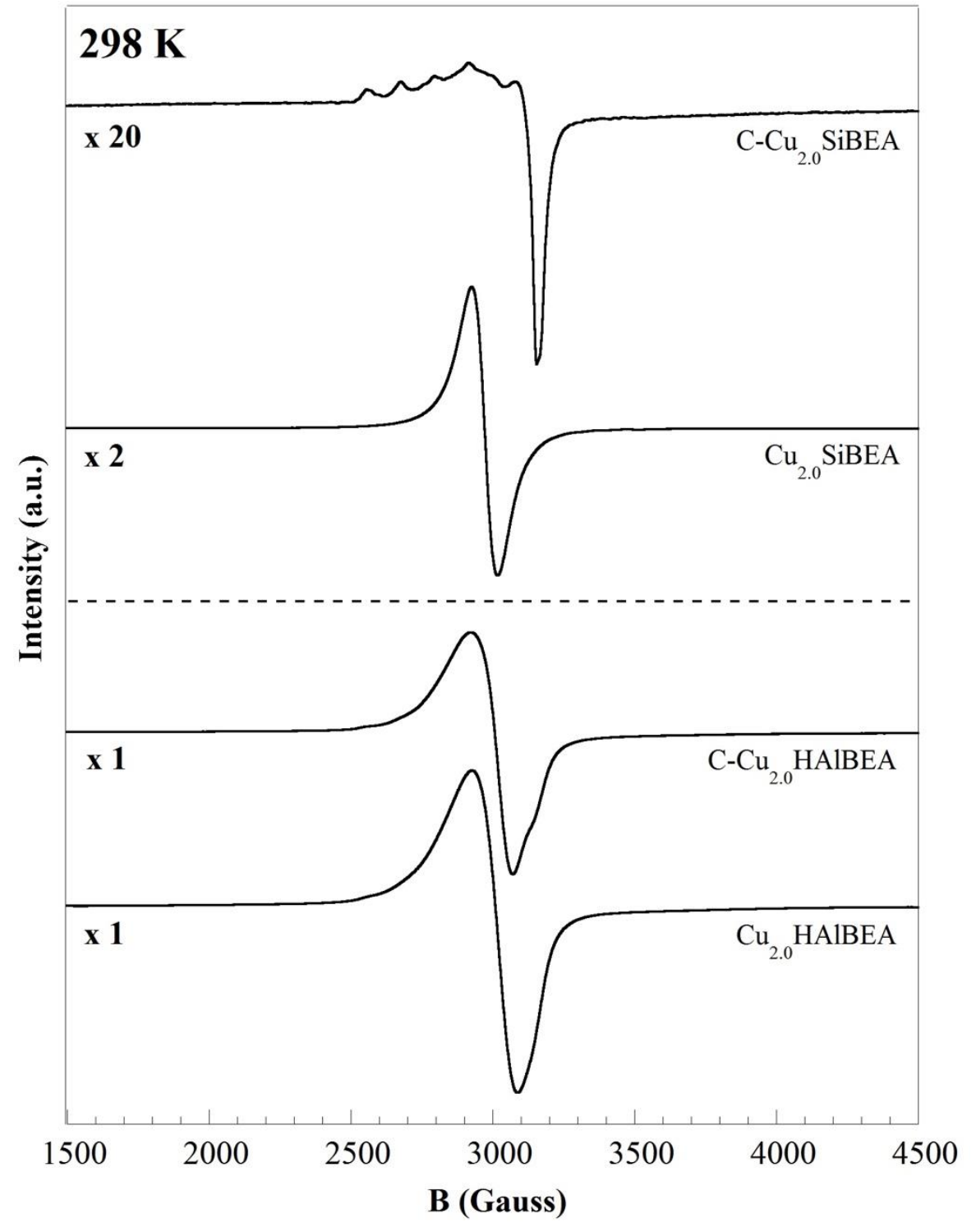

Figure 4 


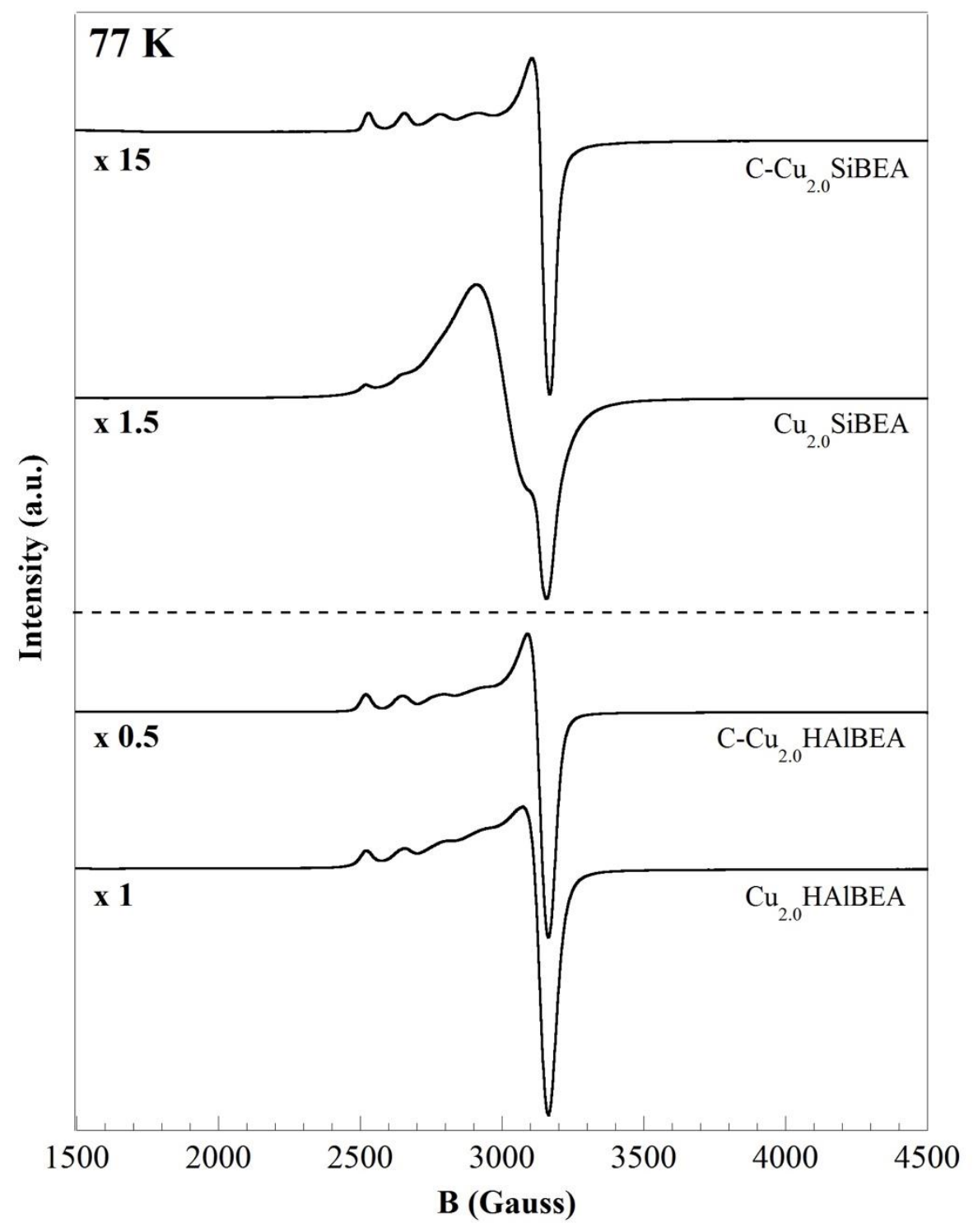

Figure 5 

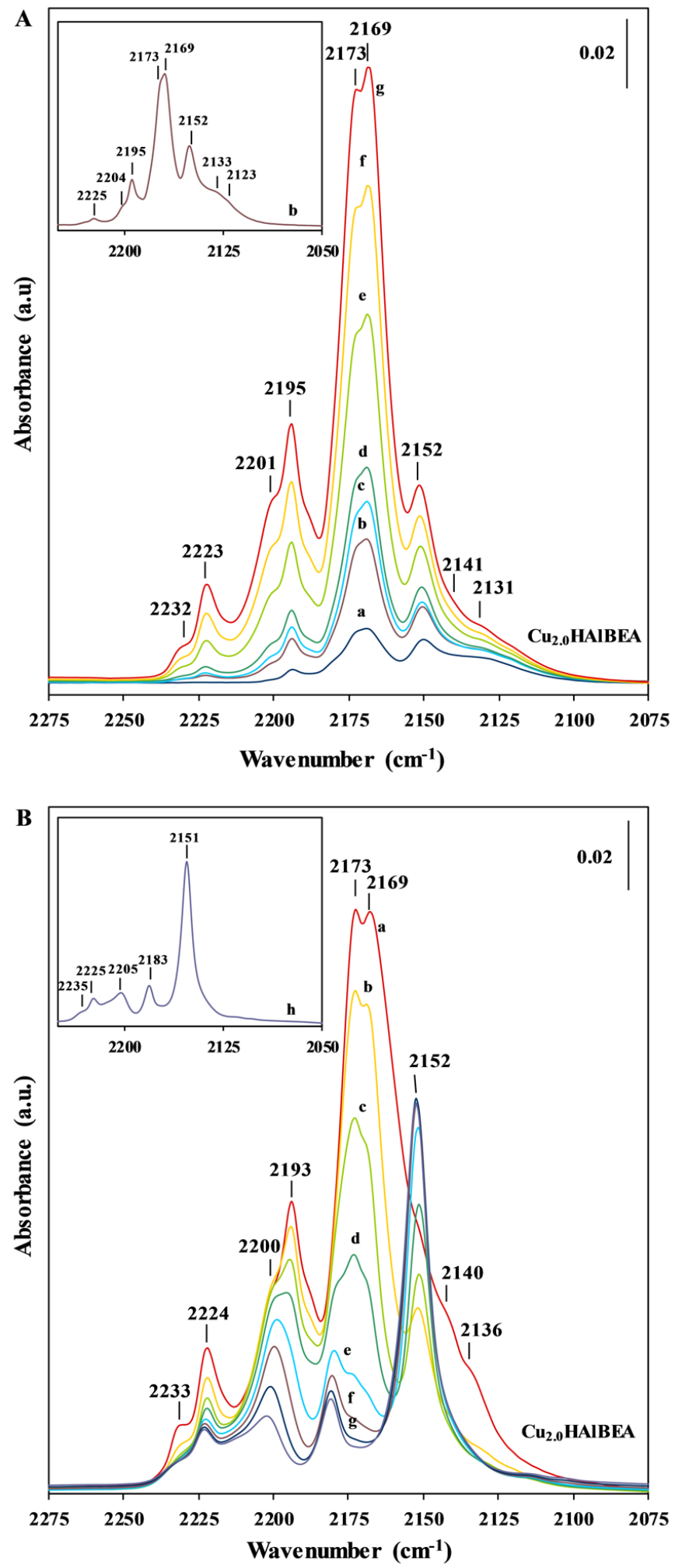

Figure 6 

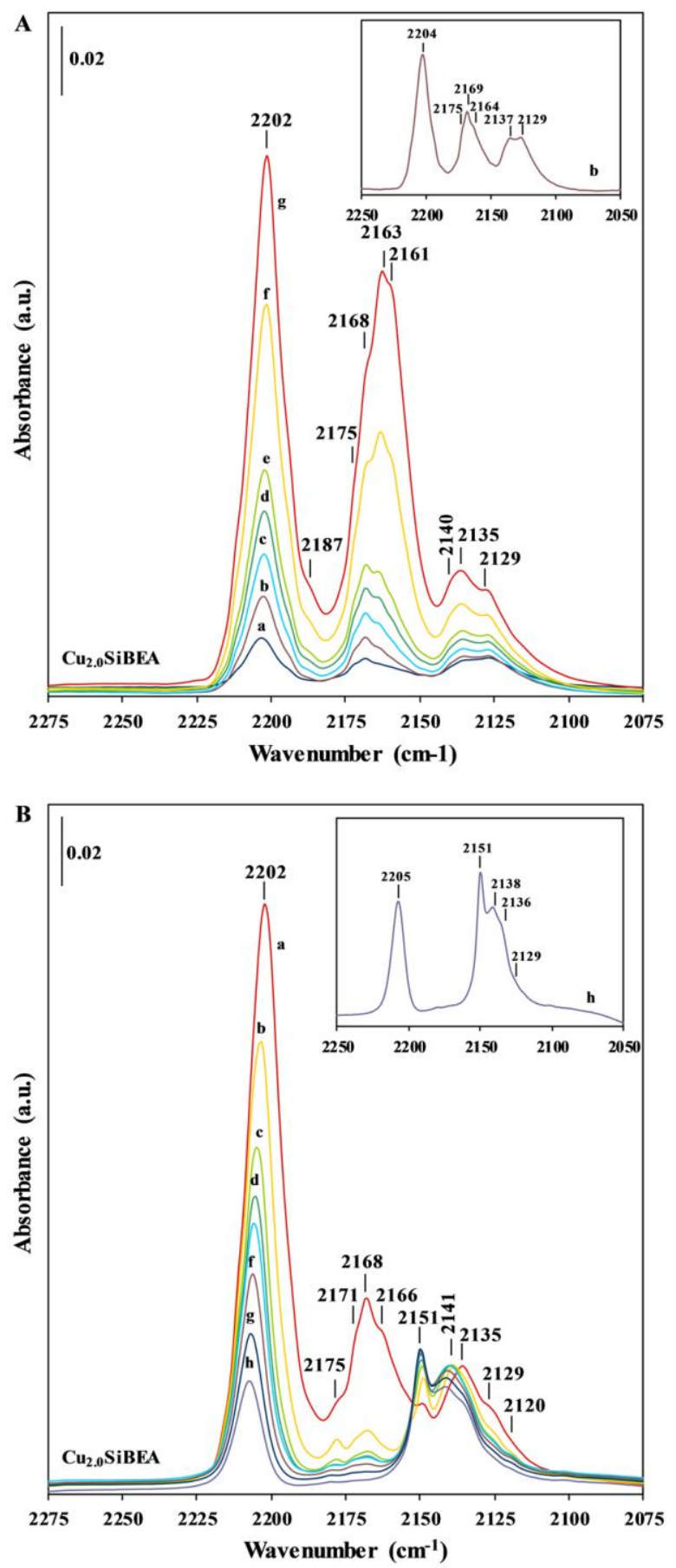

Figure 7 


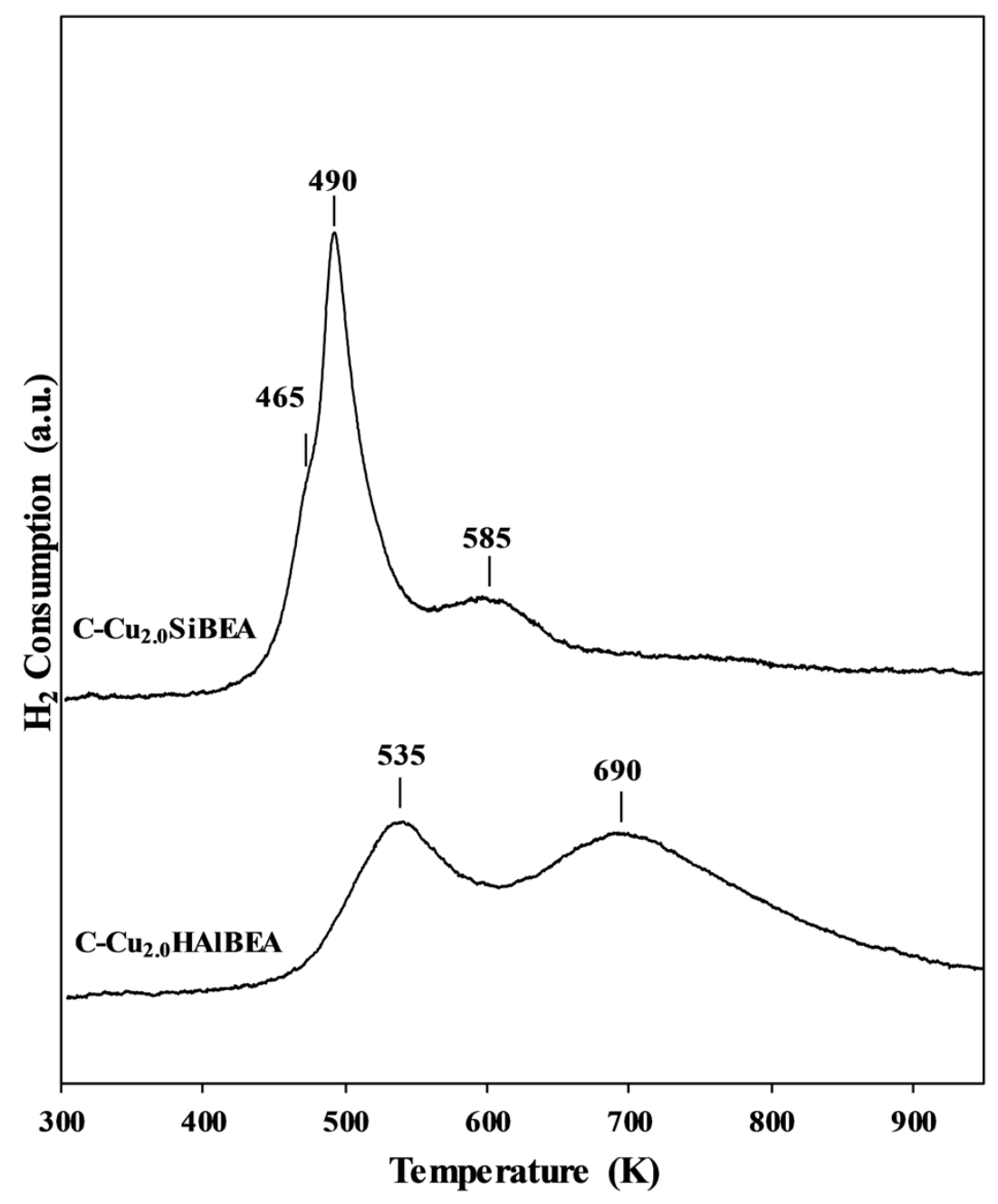

Figure 8 


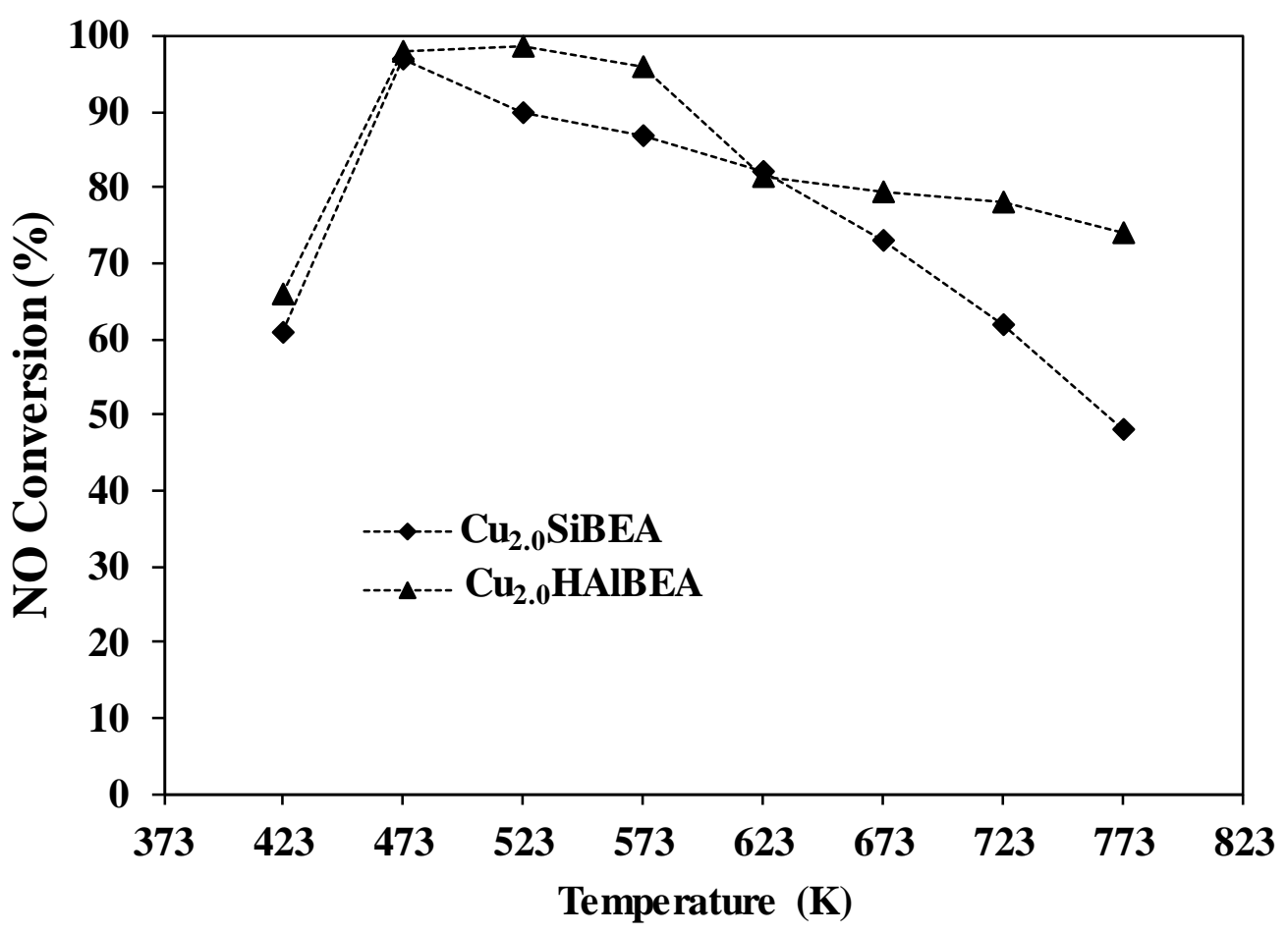

Figure 9 


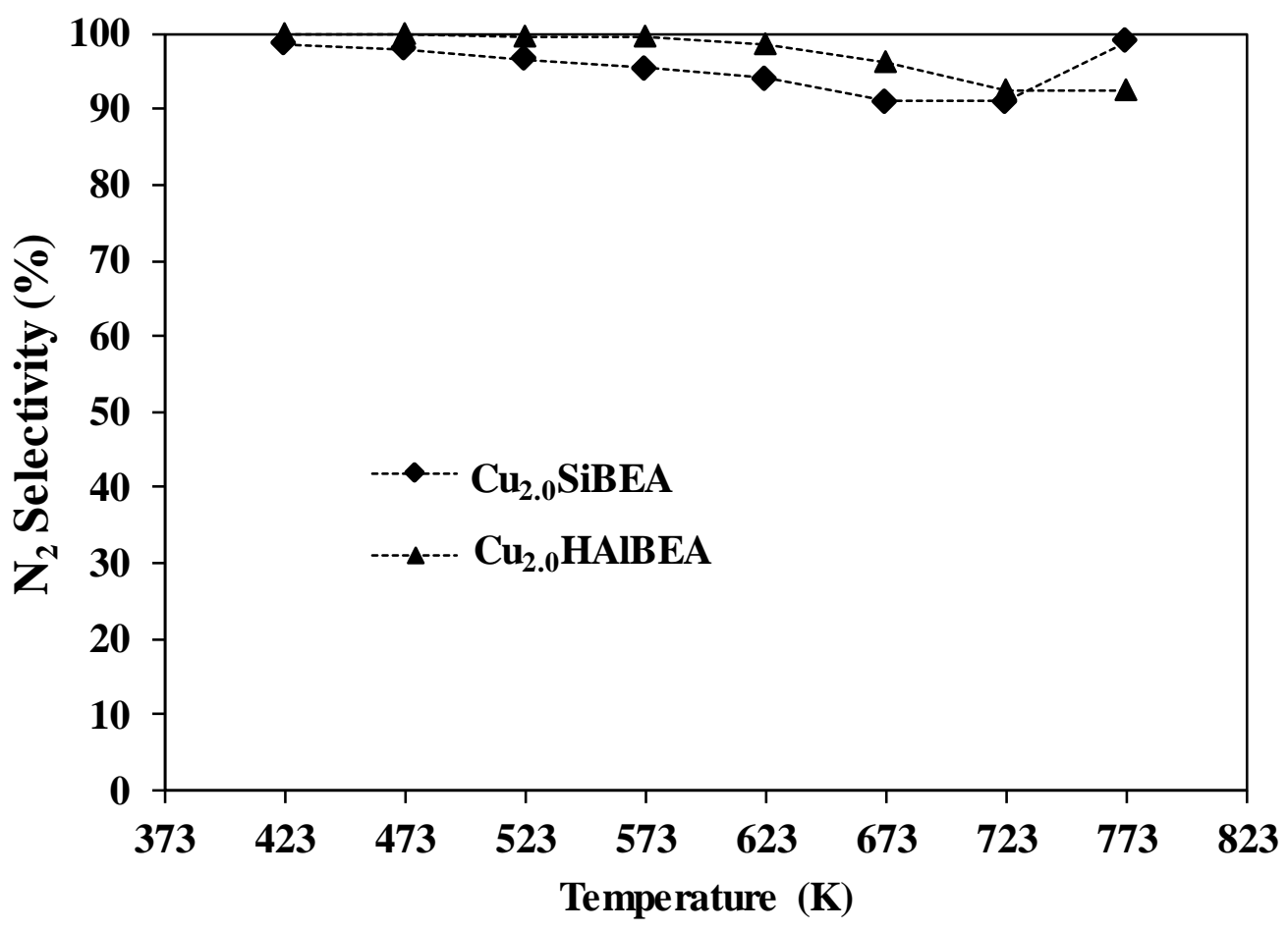

Figure 10 
Table 1. Chemical composition of BEA samples.

\begin{tabular}{|l|l|l|}
\hline Sample & Cu concentration (wt. \%) & Si/Al ratio \\
\hline TEABEA & - & 17 \\
\hline HAIBEA & - & 20 \\
\hline Cu2.0HAIBEA & 2.16 & 20 \\
\hline SiBEA & - & $>1000$ \\
\hline Cu2.0SiBEA & 2.18 & $>1000$ \\
\hline
\end{tabular}


Table 2. Simulated EPR parameters of $\mathrm{Cu}$ (II) present in $\mathrm{Cu}_{2.0} \mathrm{HAlBEA}$ and $\mathrm{Cu}_{2.0} \mathrm{SiBEA}$.

\begin{tabular}{|c|c|c|c|c|c|c|}
\hline Samples & Treatment & Measurement T & $\mathbf{g}_{\|}$ & $A_{\|}$(Gauss) & $\mathbf{g}_{\perp}$ & Relat. Int. \\
\hline \multirow{5}{*}{ Cu2.0HAIBEA } & \multirow{2}{*}{ As prepared } & $298 \mathrm{~K}$ & 2.29 & - & 2.15 & - \\
\hline & & $77 \mathrm{~K}$ & 2.39 & 135 & 2.08 & - \\
\hline & \multirow{3}{*}{ Calcined } & \multirow{2}{*}{$298 \mathrm{~K}$} & 2.26 & - & 2.16 & Major \\
\hline & & & 2.37 & 135 & 2.08 & minor \\
\hline & & $77 \mathrm{~K}$ & 2.39 & 130 & 2.08 & - \\
\hline \multirow{6}{*}{ Cu2.0SiBEA } & \multirow{3}{*}{ As prepared } & $298 \mathrm{~K}$ & $2.19\left(\mathrm{~g}_{\text {iso }}\right)$ & - & - & - \\
\hline & & \multirow{2}{*}{$77 \mathrm{~K}$} & 2.30 & - & 2.15 & Major \\
\hline & & & 2.41 & 125 & 2.08 & minor \\
\hline & \multirow{3}{*}{ Calcined } & \multirow{2}{*}{$298 \mathrm{~K}$} & 2.30 & - & 2.10 & minor \\
\hline & & & 2.38 & 120 & 2.08 & Major \\
\hline & & $77 \mathrm{~K}$ & 2.39 & 125 & 2.07 & - \\
\hline
\end{tabular}

* Estimated errors : g values (last digit \pm 3$), \mathrm{A} \|$ values ( \pm 2 Gauss),

* $\mathrm{A}_{\perp}$ is unresolved for all experimental spectra, but estimated to 10-15 Gauss for simulation purposes 
Table 3. Amounts of Brønsted and Lewis acidic centers in HAIBEA, Cu2.oHAlBEA, SiBEA and Cu2.0SiBEA

\begin{tabular}{|l|l|l|}
\hline Sample & $\begin{array}{l}\text { Brønsted acidic centers } \\
\left(\mu \mathrm{mol} \mathrm{g}^{-1}\right)\end{array}$ & $\begin{array}{l}\text { Lewis acidic centers } \\
\left(\mu \mathrm{mol} \mathrm{g}{ }^{-1}\right)\end{array}$ \\
\hline HAlBEA & 333 & 137 \\
\hline $\mathrm{Cu}_{2.0} \mathrm{HAlBEA}$ & 176 & 342 \\
\hline SiBEA & 8 & 3 \\
\hline $\mathrm{Cu}_{2.0} \mathrm{SiBEA}$ & 3 & 52 \\
\hline
\end{tabular}


Table 4. Percentage of copper reduction in $\mathrm{Cu}_{2.0} \mathrm{SiBEA}$ and $\mathrm{Cu}_{2.0} \mathrm{HAlBEA}$ samples calculated from TPR data

\begin{tabular}{|c|c|c|c|c|}
\hline Sample & $\begin{array}{l}\mathrm{Cu} \text { content, } \\
\mathrm{C}_{\mathrm{Cu}} \\
(\%)\end{array}$ & $\begin{array}{l}\text { Sample mass, } \\
m_{s} \\
(\mathrm{~g})\end{array}$ & $\begin{array}{l}\text { Total surface of TPR } \\
\text { peaks, } S_{s} \\
\text { (a.u.) }\end{array}$ & $\begin{array}{l}\mathrm{Cu} \text { reduction } \\
\text { degree, } R_{C u} \\
(\%)\end{array}$ \\
\hline $\mathrm{Cu}_{2.0} \mathrm{SiBEA}$ & 2.18 & 0.1150 & 4975 & 65 \\
\hline $\mathrm{Cu}_{2.0} \mathrm{HAlBEA}$ & 2.16 & 0.1134 & 7074 & 100 \\
\hline
\end{tabular}

